\title{
الفنون والحرف الشعبية كمدخل لإثراء هناهج الفن والتربية الفنية في ضوء إستراتيجية التطوير
}

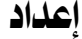 \\ د/ وليد سعود العنزيك \\ الأستاذ المساعد بقسهم التربية الفنية

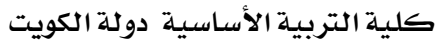

مجلة بحوث التربية النوعية - جامعة المنصورة

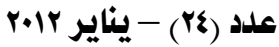




\section{في ضوى إستزاتيهية التطوير}

إعداد

د/وليد سعود العنزى

مقدمهة:

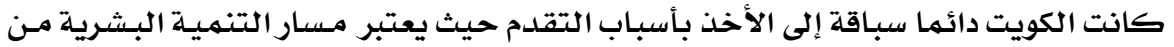

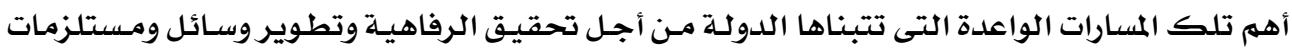

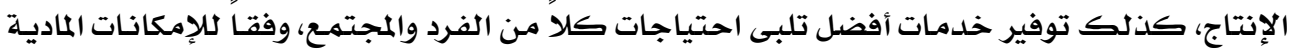

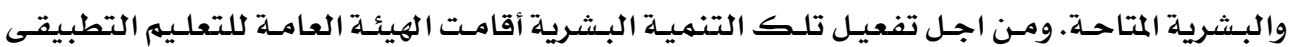

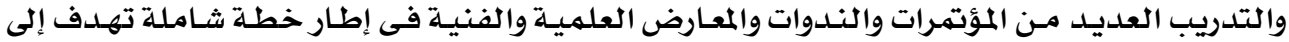

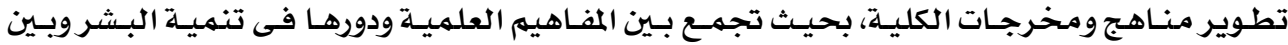

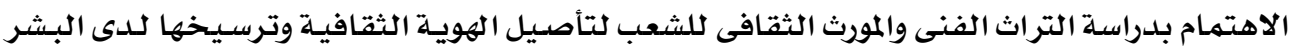

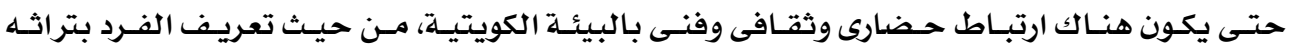

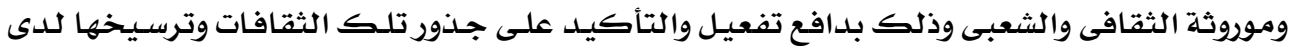

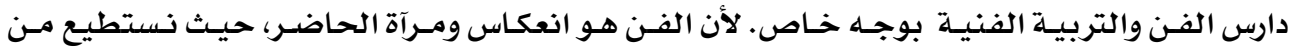

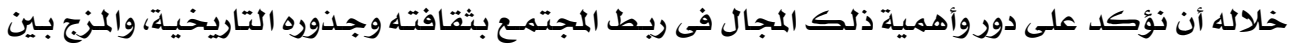

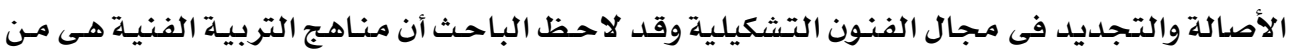

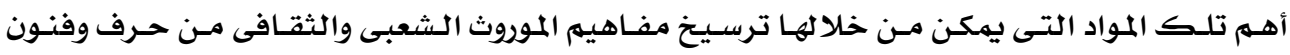

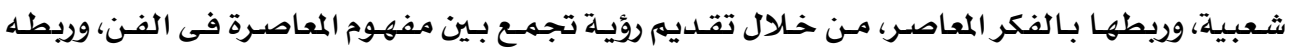

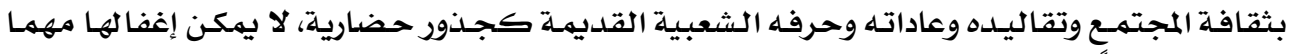

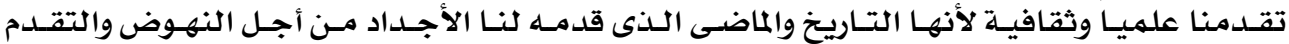

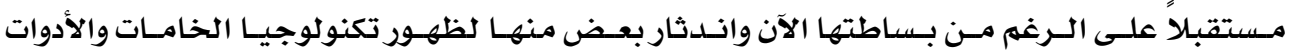

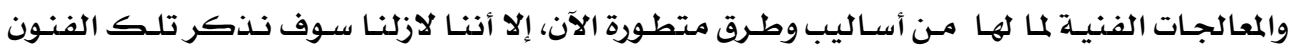

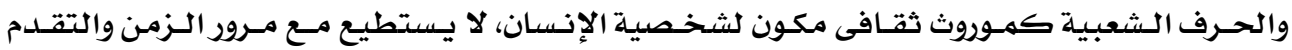

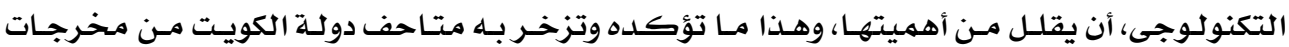

$$
\text { التراث الفنى والشعبى الكويتى على مر السنين. }
$$

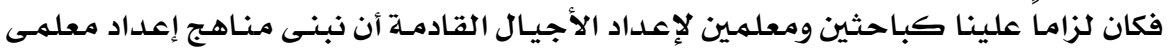

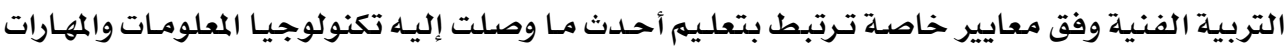




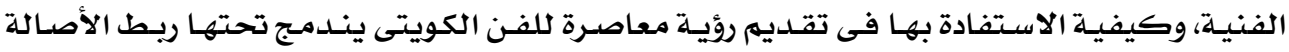

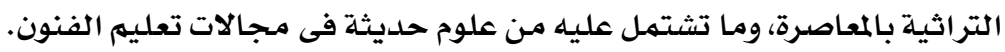
ومند زمن طويل تأكد للباحثين والمفكرين أهمية ودور التربية الفنية كمادة محورية تسعى

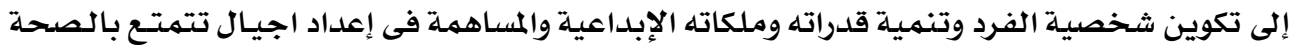

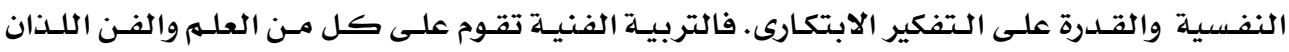

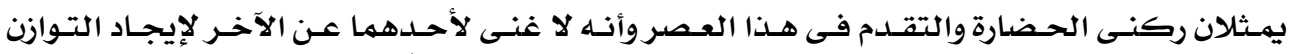

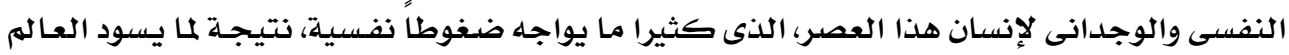

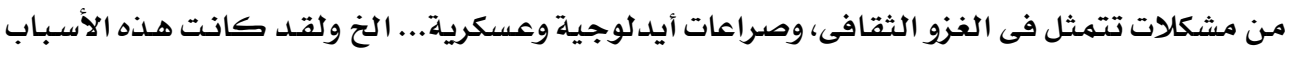

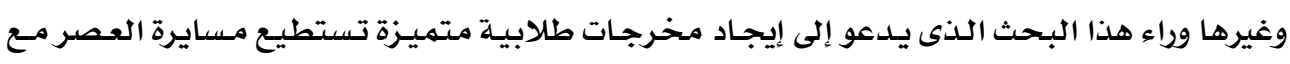

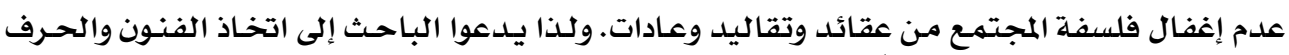

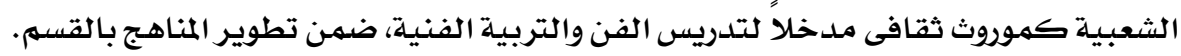

لقد حظى قطاع الفنون والحرف الشعبية والصناعات اليدويـة باهتمـام واسـع فى معظبم دول

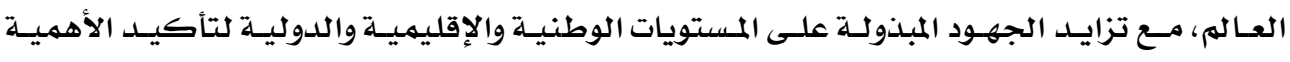

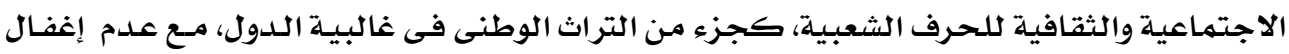

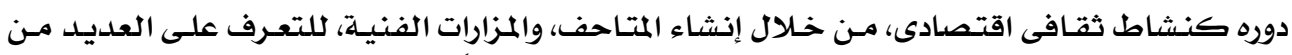

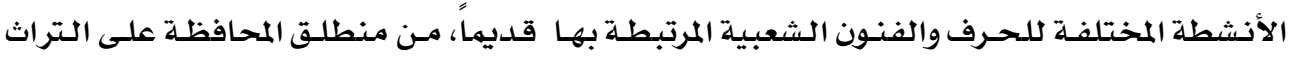

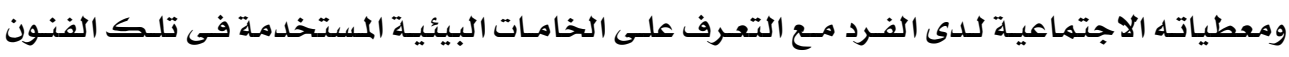

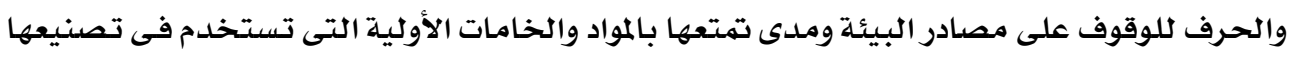
كثروة قومية.

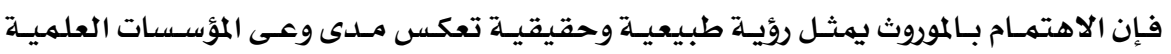

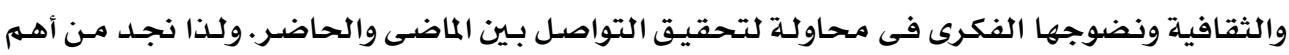

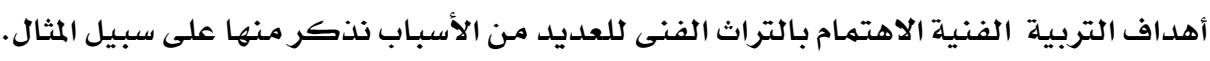

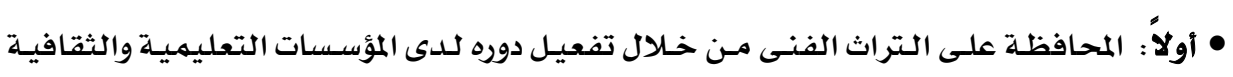
بدولة الكويت لتأكيد الهوية الوطنية.

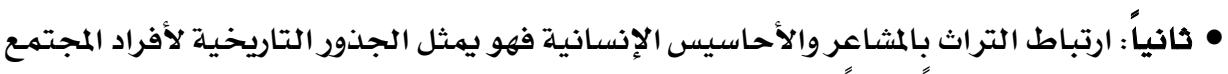

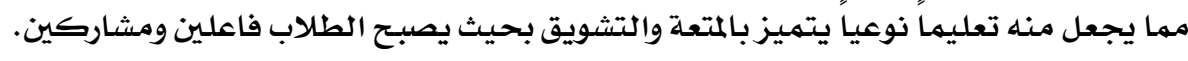

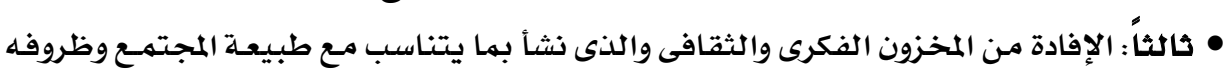
كمدخل للتعليه وتحقيق التوازن بين ما هو موروث ومعاصر.

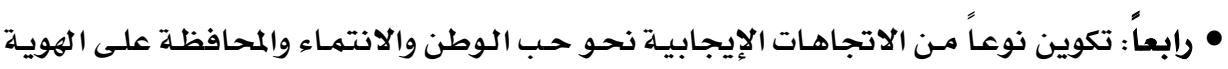
بما لها من معانى ودلالات. 
مجلة بحوث التربية النوعية - علد ع - ميناير r.lr

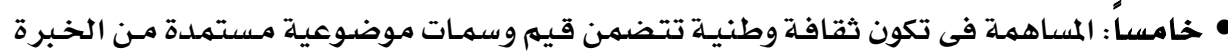
والتجريـة التراثية، بحيث تسـاير العصر وتعهـل على ترسيخ العديــ مـن الاتجـاهـات نحـو العمـل

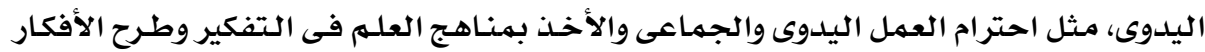

$$
\text { الإبـداعيـة. }
$$

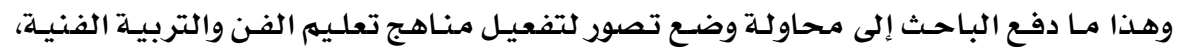
بأهميته ودور التراث الشعبى والحرف الشعبية القديهـة، وتقديمها برؤية جديلدة، وفق متطلبـات العصر الحديث، مـع توضيح أهمية ودور التراث الفنى القـديهم فى مخرجـات الفنـون الحديثة، لتاصسيل الهويـة الثقافيـة والتراثيـة لـدى دارسـى التربيـة الفنـيـة ونقلـها بـالتبعيـة لـلأجيـال القادمــة، بهــارس التعلـيهم المختلفة حتى يكون هناك اتصال فكرى تراثى حضارى عبر الأزمنـة. همشكاة البحث:

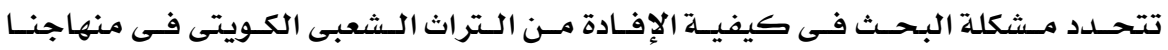
كمدخلات لتـريس الفن والتربية الفنية لطلاب قسهم التربيـة الفنيـة، كليـة التربيـة الأسـاسية بلدولـة الكويت فى ظل نظـام عـالمى جديـد يـدعو إلى العولمة وتذويب الثقافات المحليـة وإحـلال ثقافات غربيـة

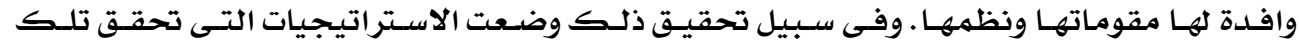

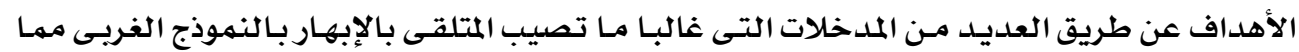

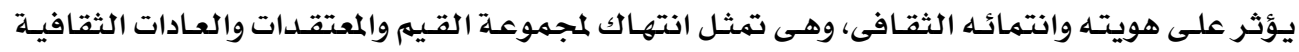
والعربية والإسـلاميـة. فهى اختراق لنظم الحيـاة دون سـابق انذار، كمـا أنها تمثل خطورة على الموروث

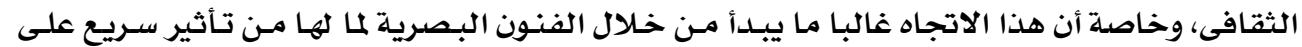

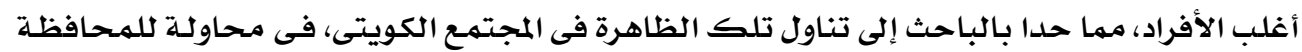

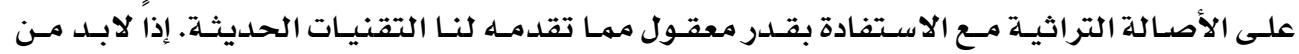
الاستمـرار فى تعزيز الشخصية الإسـلامية الأصيلة فى كافة فروع الحرف اليدويـة الشعبية، ولن يأتى ذلك إلا عندما يُتخخذ مـن الفنـون والحـرف الشعبيـة الكويتيـة مـدخلا لتـدريس الفن والتربيـة الفنيـة بهـراحل التعليهم المختلفة. تهديد الاشبكانة:

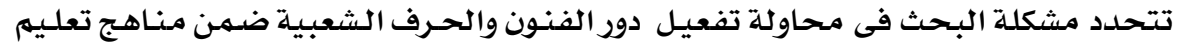

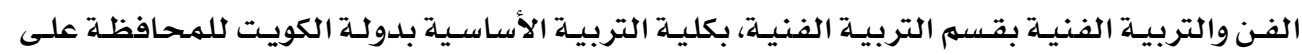

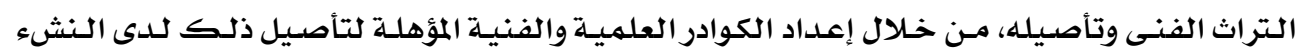
بالمدارس فى المستقبـل.

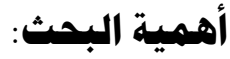

• محاولتة قراءة تاريخ الفنـون والحـرف اليدويـة فى دولـة الكويت واستثهـارها فى تحقيـق التوافق والتزاوج بين التراث ومتطلبـات الحياة العصرية. 


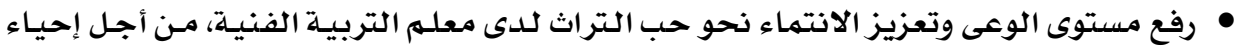

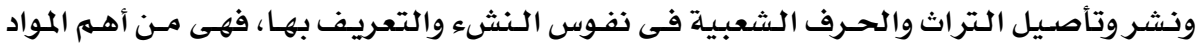

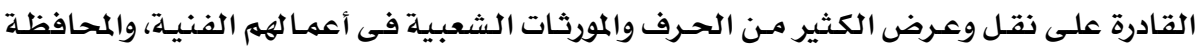

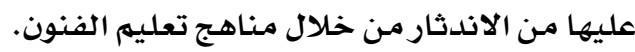

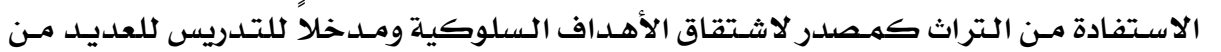

إبراز دور التربية الفنية فى المحافظة على الفنون والحرف الشعبية الكويتية القديهـة من خـلال

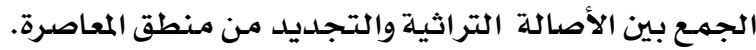

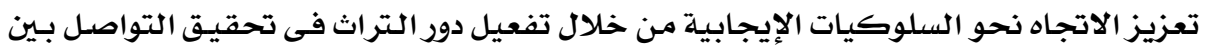
الماضى والحاضر.

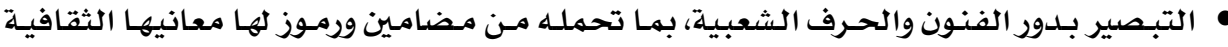

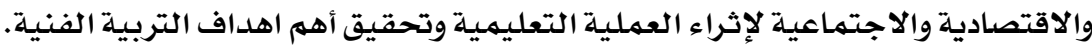

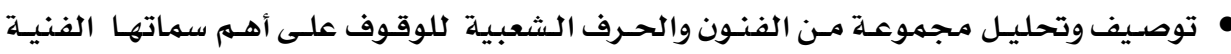
والتشكيلية. • التأكيد على دور مناهج تعليم الفنون والتربية الفنية فى التعريف والتأصيل التراثى للفنـون

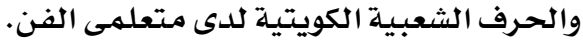

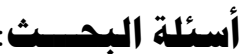

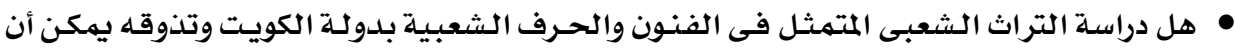

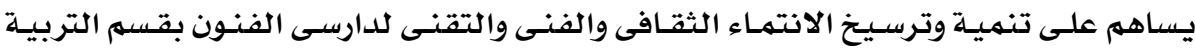
الفنية • هل يهكن أن نتخذ من الفنون والحرف الشعبية مدخلا لتدريس الفن والتربية الفنيـة فى ضوء

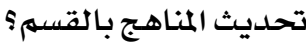

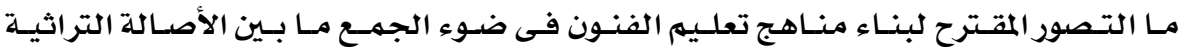

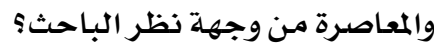
هدود البحث:

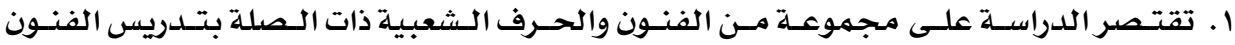

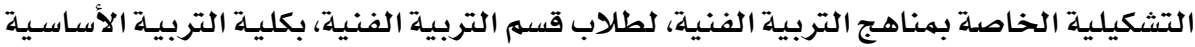
. دولة الكويت.

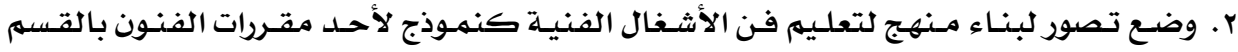

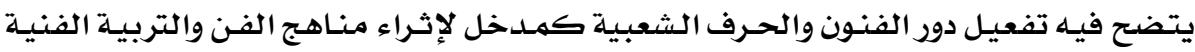
على طريقة الـ Wids. 
يتبـع الباحـث المـهـج التـاريخى والوصـفى (الوثـائقى) التحليلـى فى ضـوء وأبعـاد المشكلة

هي تلـك المهـن التي يزاولها حرفيـون مهرة بـلا أيـة معاونة مـن آلـة تحركها الطاقـة، وريما

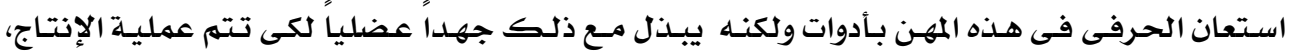

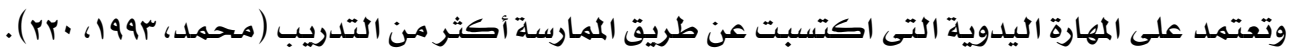

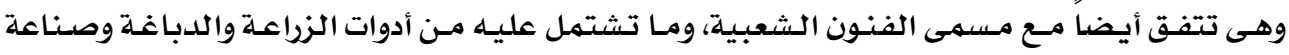

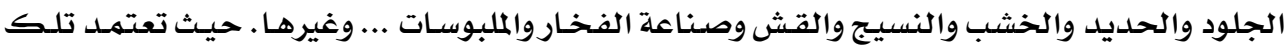

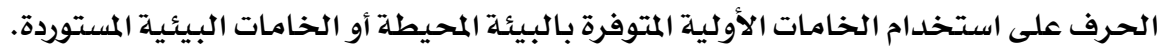

\section{م التربية الفنية:}

التربية الفنية هى التربيـة عن طريـق الفن وتهـدف إلى ترقيـة ونهو التلاميذ والطلاب فنيـاً

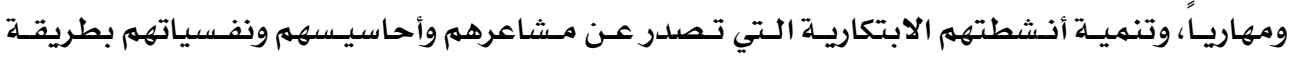

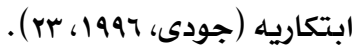

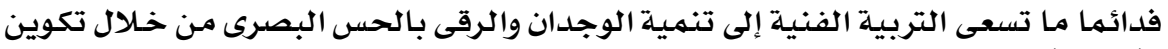

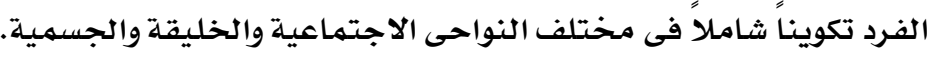

\section{التربية الفنية وارتباطها بالفنون والحرف الشعبية:}

تسعى التربية الفنية دوماً من خلال بعض أهدافها إلى تقدير واحترام العهـل اليدوىى، وتفهـم

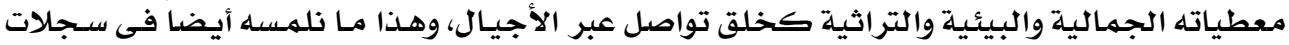

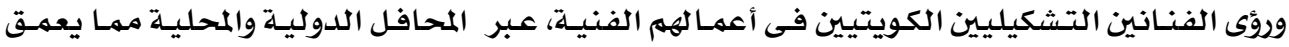

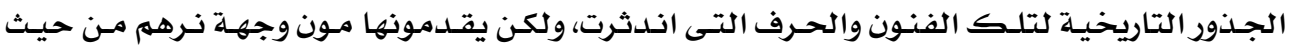

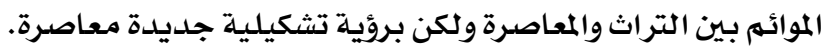

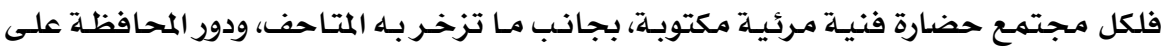

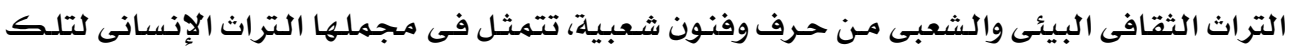

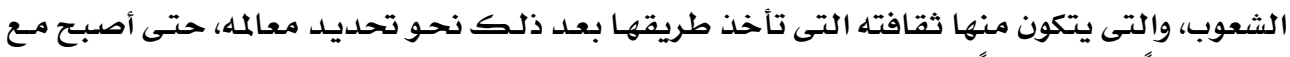

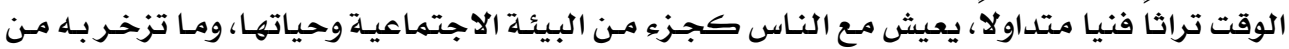

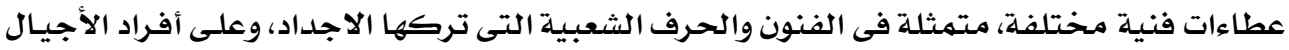

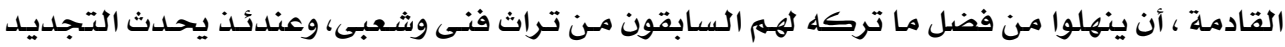

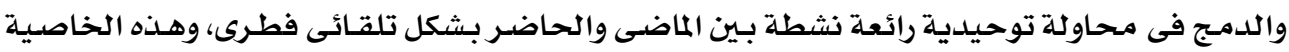


وحلدها هى التى تجعل المجتمـع لا يتوقف ابدا عن العطاء الثقافى التعبيرى الذنى يتمثل فى مضمونه

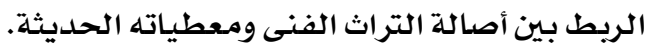

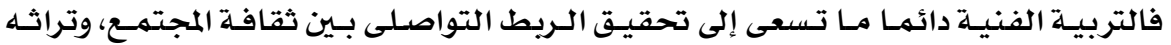

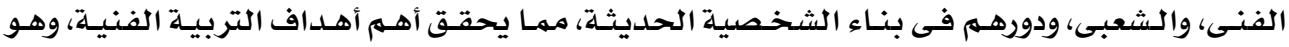

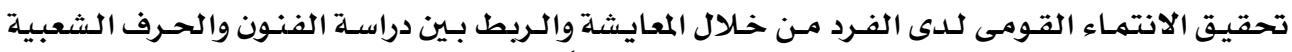

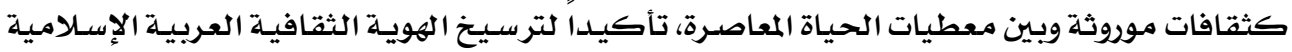
لدى النشء في المستقبل.

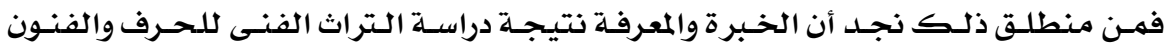

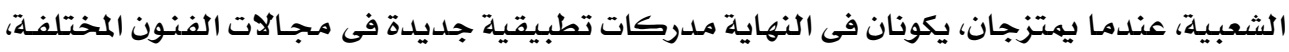

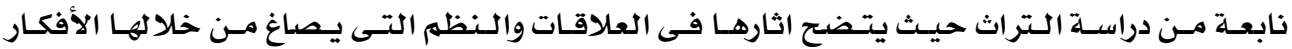

التعبيريـة الجديدة.

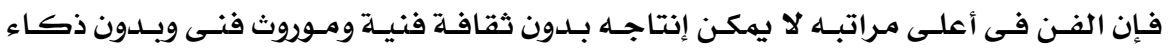

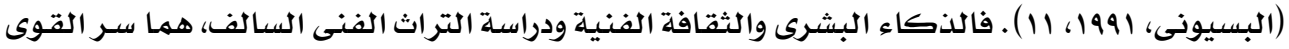

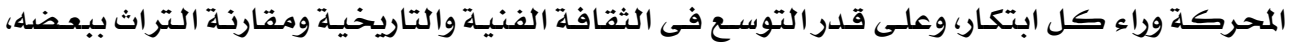

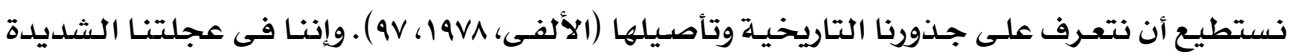

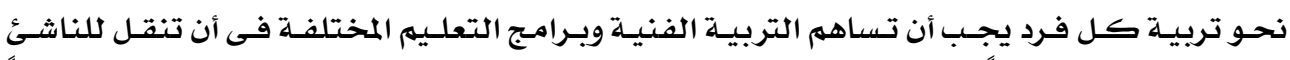

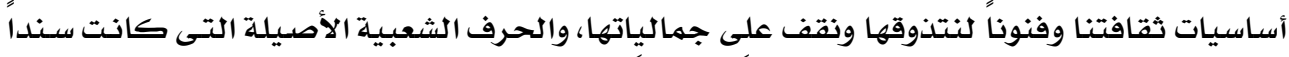

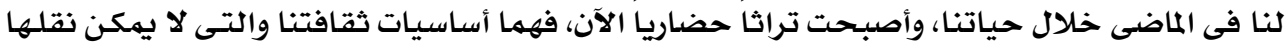

إلا بالتربية الفنية والممارسة الفنية لها.

فالثقافة الفنية الشعبية، هى إحدى ثقافات المجتمعات المتحضرة الآن، لما تؤكده على أهميـة ألماتية

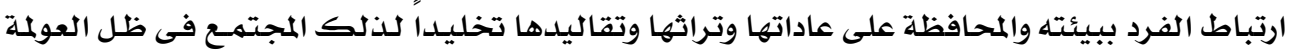

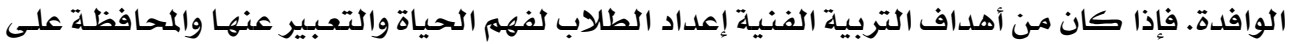

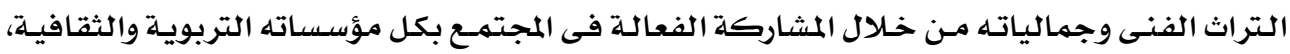
بين منطق اعتبار أن الفنون والحرف الشعبية هى المصلدر الرئيسى لتحقيق تلكي الكئ الأهداف.

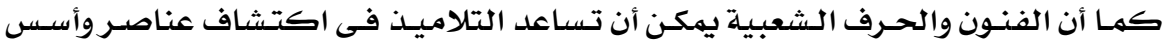

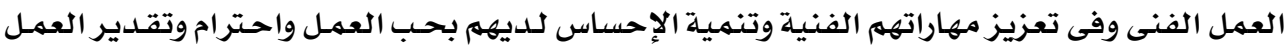

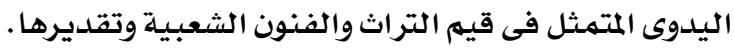

فهن هذا المنطلق كان لزاماً على معلمى التربية الفنية أن يكونوا قادرين على إيجـاد علاقـة

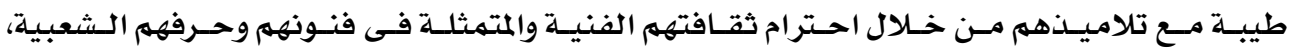

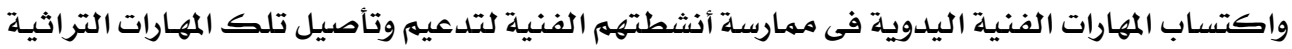

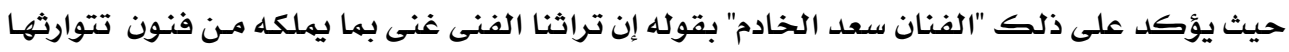




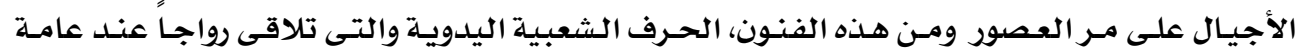

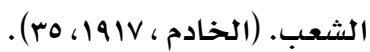

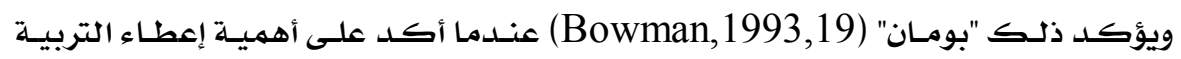

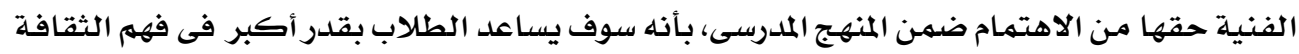

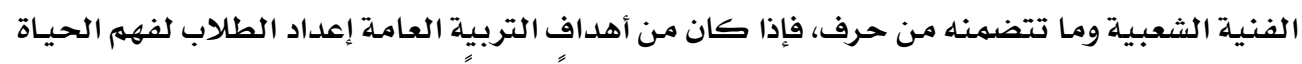

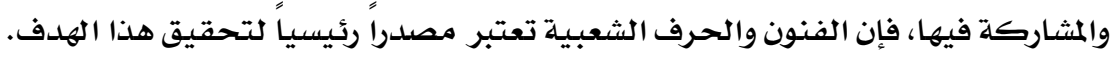
كما أن الفنون الشعبية يهكن أن تساعد التلاميذ فى اكتشاف عناصر وأسس العمل الفنى،

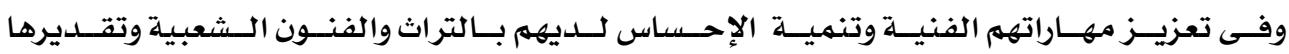
.(Nevinskas, 1991,24-27)

فالتربية الفنية تهتهم بالنهوض بمراكز التراث الفنى من أجل المحافظة على الحـرف الفنيـة

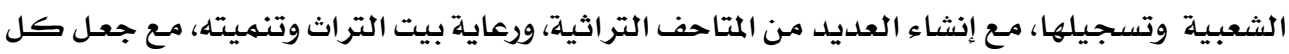

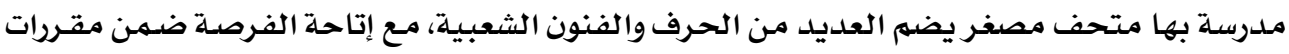

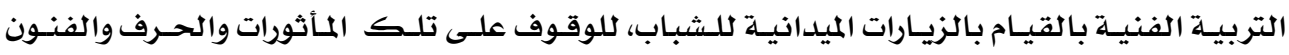

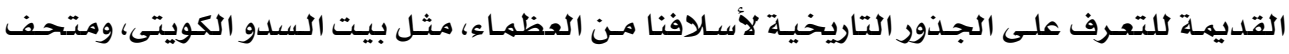

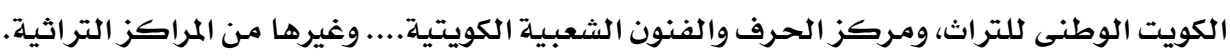
فهن ذلك المنطلق يـرى الباحث اهميـة تفعيل دور التراث الفنسى الثقافى والحرفى والفنـون

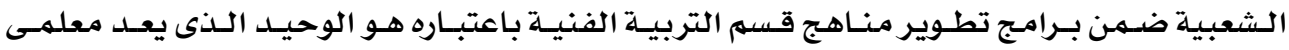

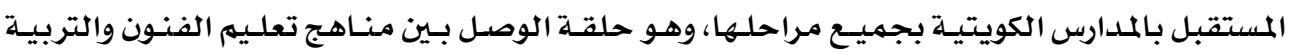

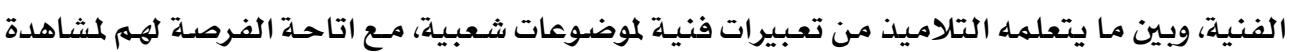

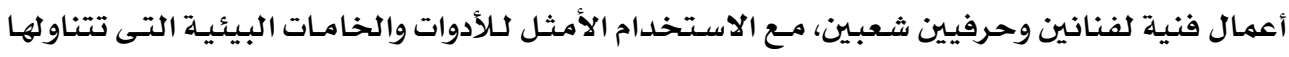

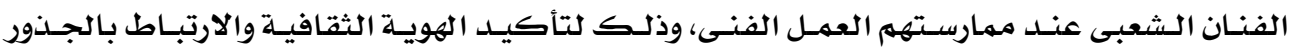
التاريخية للحرف والفنون اليدوية الشعبية الكويتية.

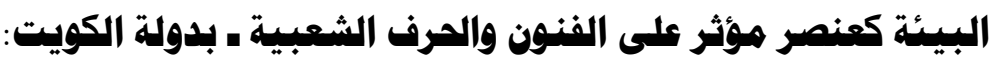

كان للتنوع والثراء البيئى بدولة الكويت آثاره على تعدد وظائف وجماليـات الفنـون والحـرف

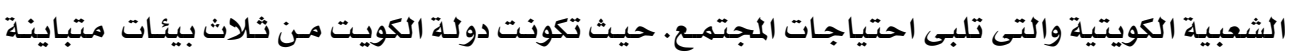

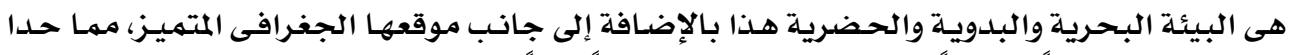

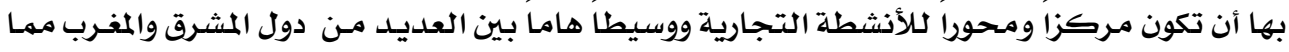

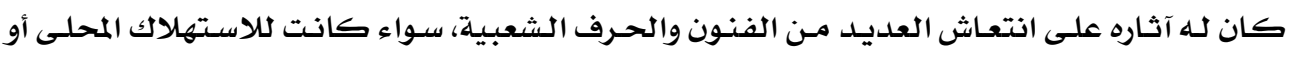

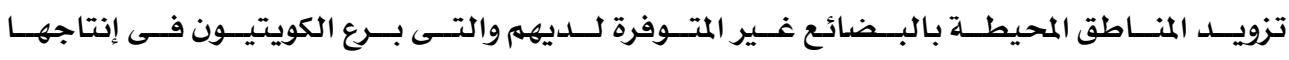

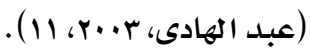


ولذا تُقسم الفنون والحرف الشعبية إلى ثلاثة أقسام:

• أولاً : فنون وحرف ذات علاقة بالبيئة البحريـة.

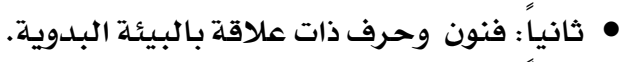

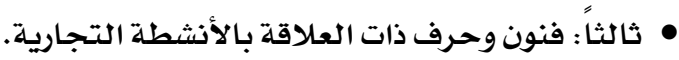

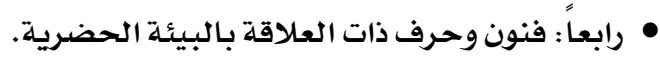

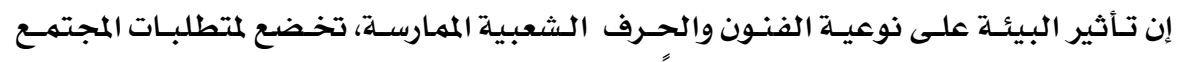

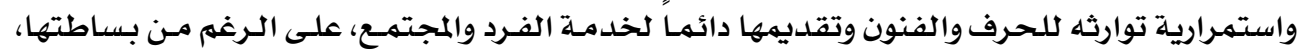

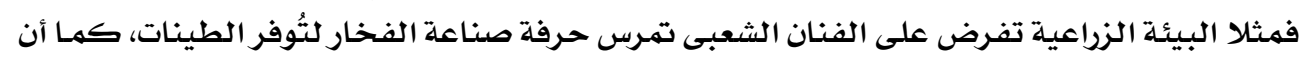

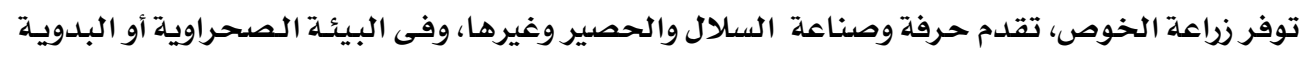

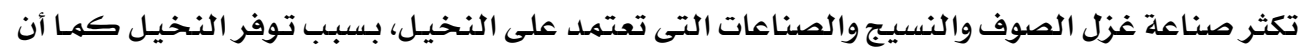

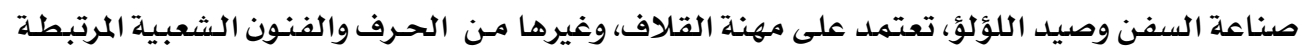

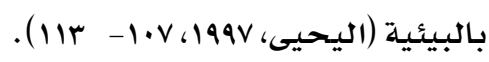

ومن خصائص الفنون والحـرف الشعبية أنها تتميز بـاستخدلـام الخامـات المحليـة البيئيـة ومـا

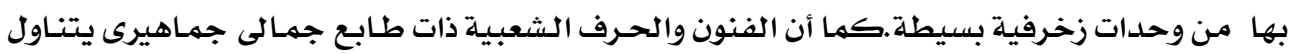

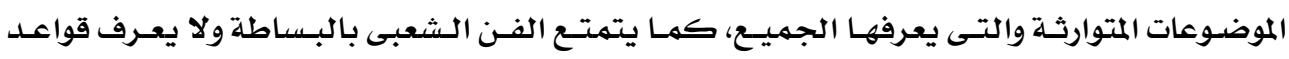

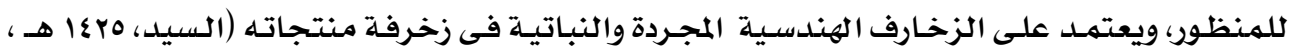
. (r. -1

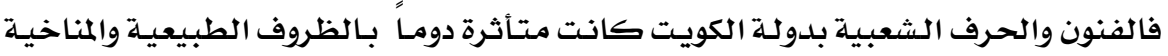

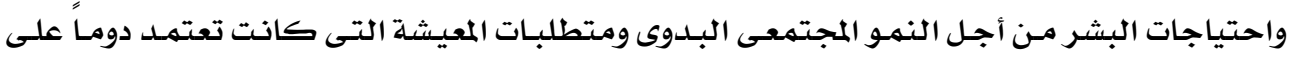

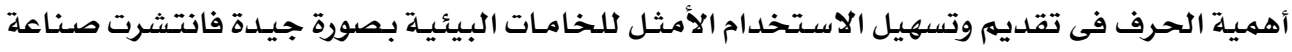

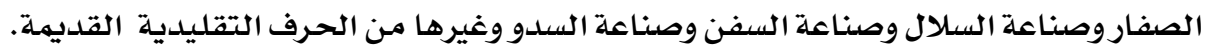

\section{تاريخ الفنون والهرف الشعبية بدولة الكويت:}

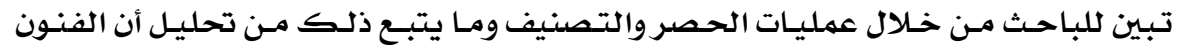

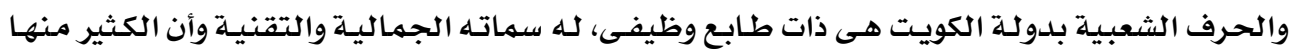

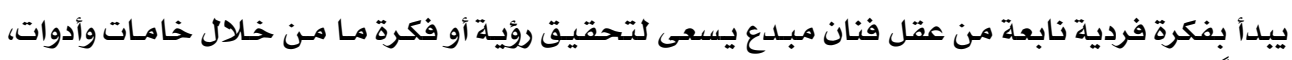

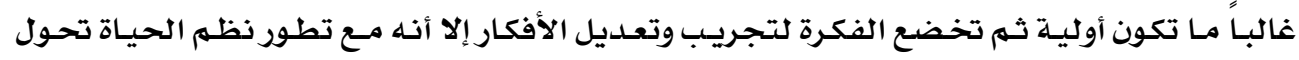

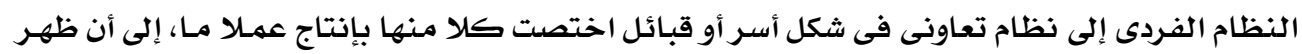

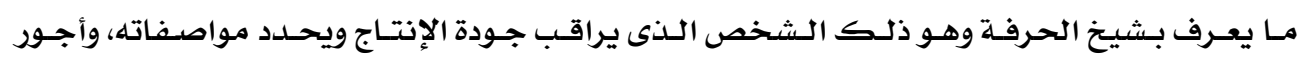

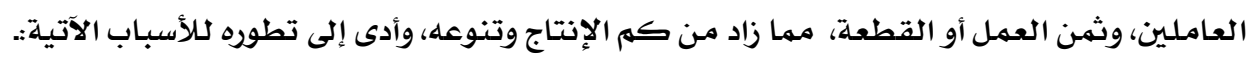

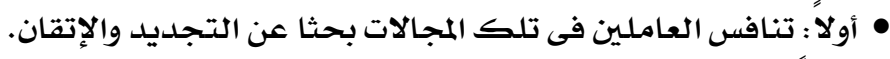

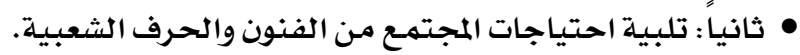


• ثالثاً : اشتغال الكثير من أبناء الكويت بالأنثطة التجاريـة أو لعب دور الوسيط مما أدى إلى رواج

$$
\text { العديد من تلك الحرف والفنون. }
$$

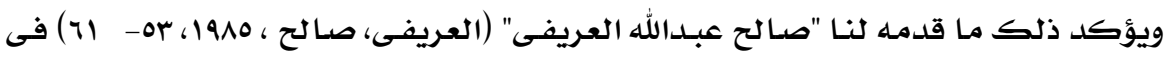

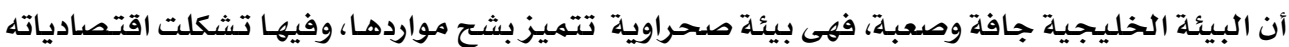

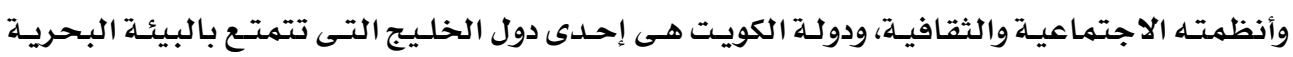
والصحراويـة.

ولما كانت مقدرات الإنسان الخليجى الثقافية محدودة بإمكانياته آنذاك فقد حددت البيئـة

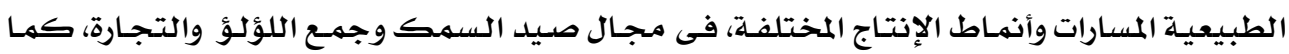

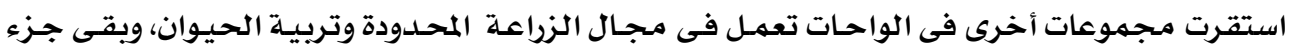

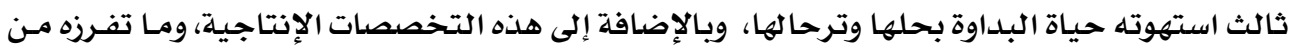

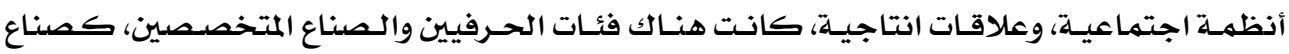

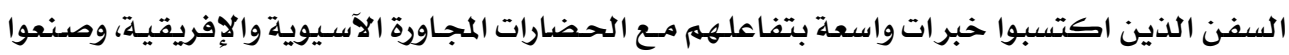

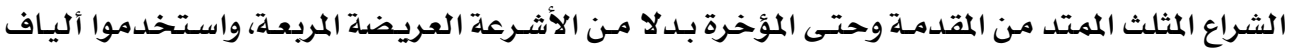

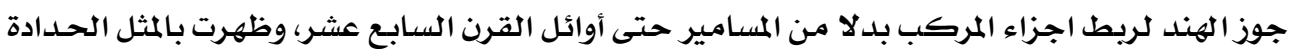

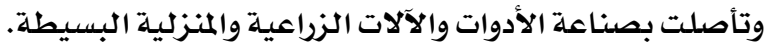

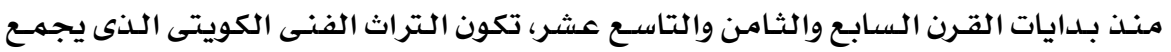

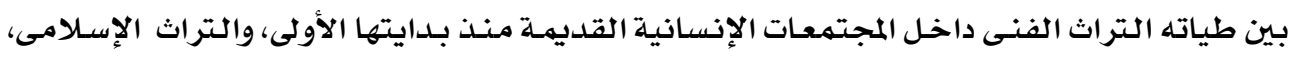

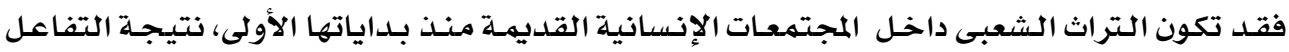

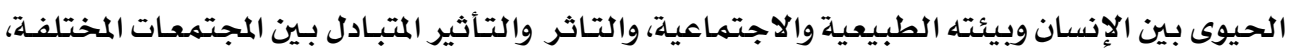

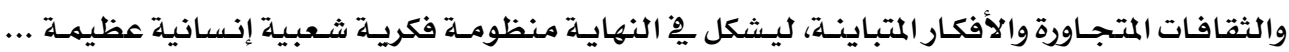

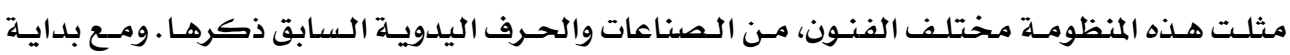

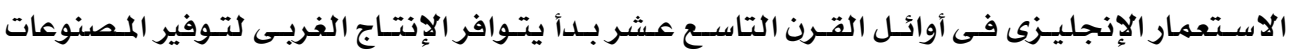

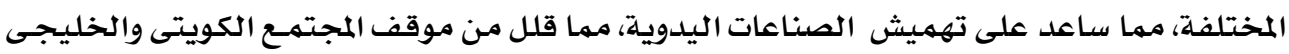

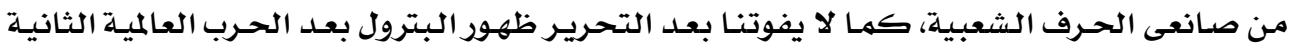

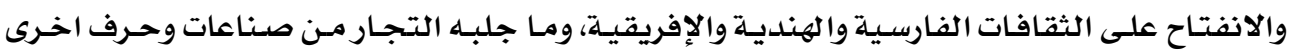

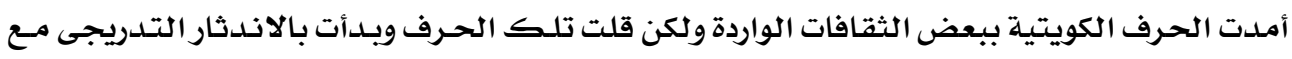

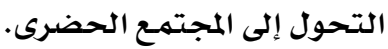

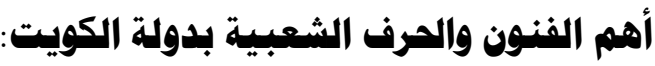

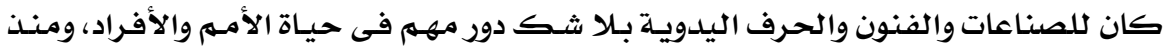

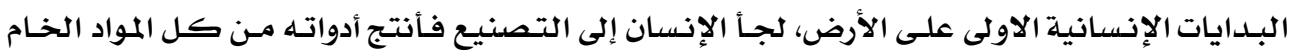

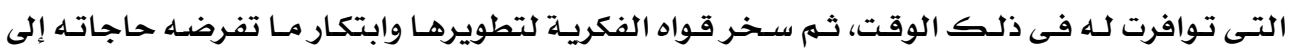


ابتكـاره مـن أدوات تـسهل أمـور حياتـه اليوميـة وتـذلل الـصعوبات التـى تواجهـهـ أثنـاء إقامتـه وتنقلسه،

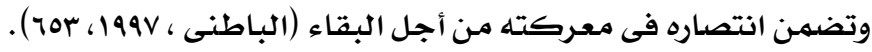

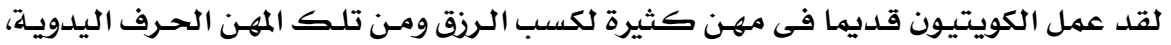

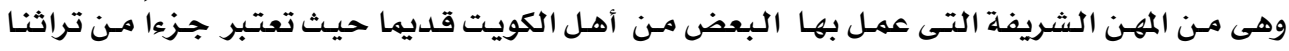

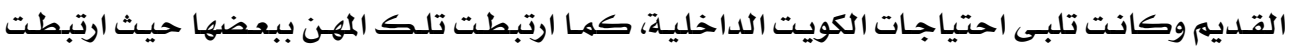

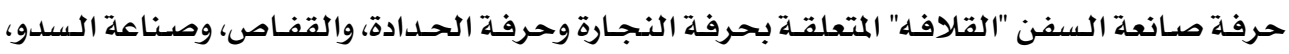

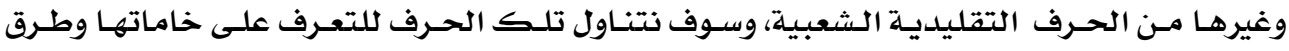
تشغيلها وقيمتها الفنية والجمالية وهى: ولتئ. أولاً: صناعات ارتبطت بحياة البحر: حرفة صناعة السفن الخشبية.

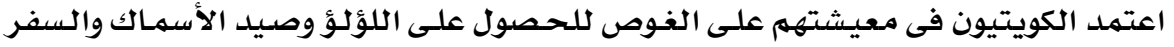

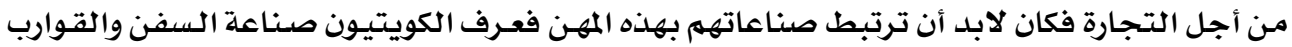
وأتقنوا كل فنونها وبرعوا وابتكروا أنواعا جديدة من السفن اشتهرة آنهرت بهم واشتهروا بها. يطلق الكويتيون على صناعة السفن اسهم "قلافة السفن" نسبة إلى "قلاف" أو "القـلاف" وهـو عامل بناء السفينة ويطلق على رئيسه هلى "رئيس القلاعليف" أو الأستاذ.

$$
\text { ومن أنواع السفن التى كانت تصنع فى الكويت: }
$$

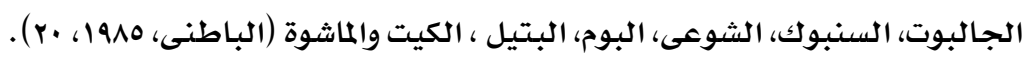

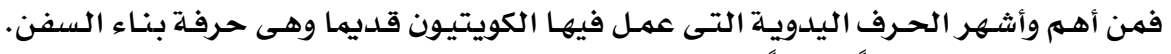

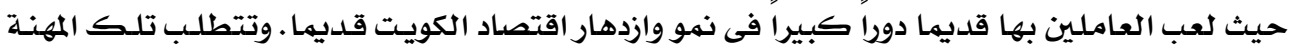

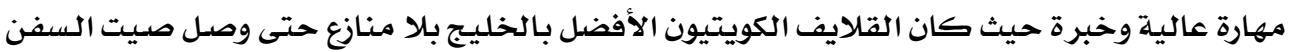

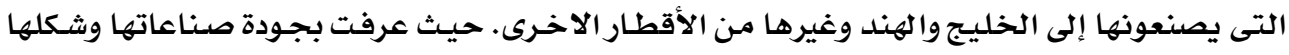

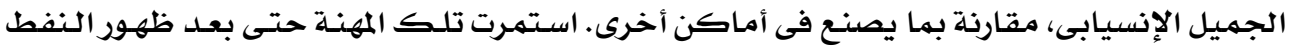

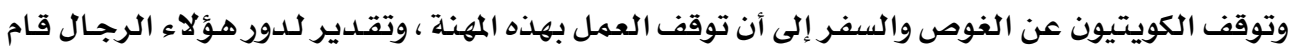

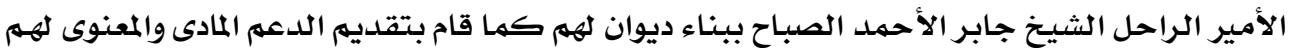

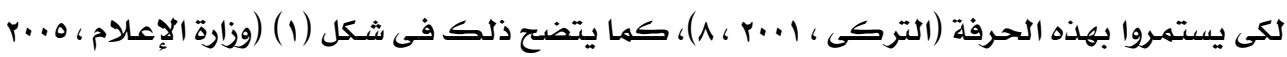

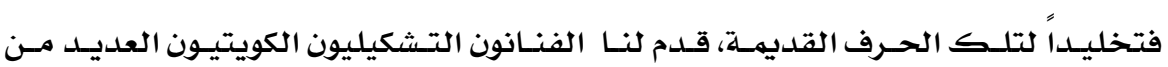

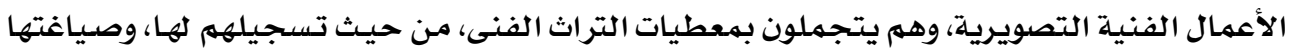

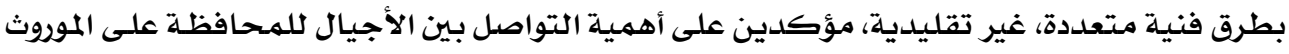
الثقافى والتراث الفنى الشعبى. 
حرفة يدوية عمل البعض من اهل الكويت ولعب العـاملين بها دور كبيرة بتوفير مستلزمات

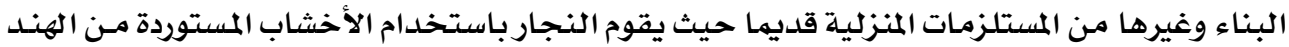

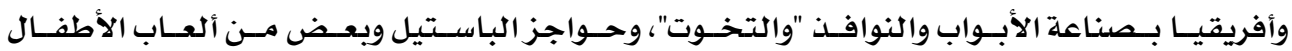

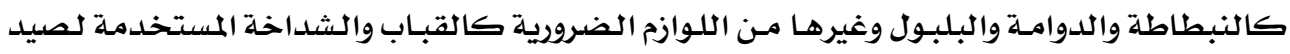

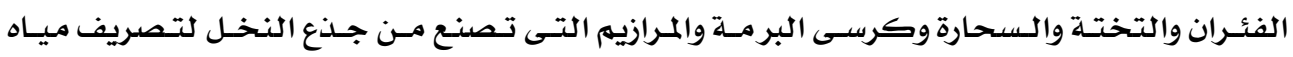

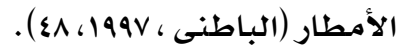

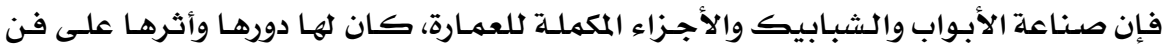

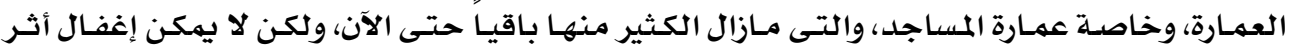

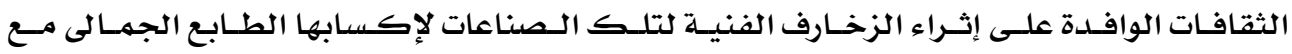

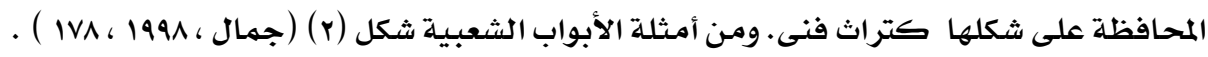
صنامة الصناديق: ومن أهمها الصندوق المبيت وكان عادة يستورد من الهند، ويستخدم لحفظ وتخزين الملابس المبس

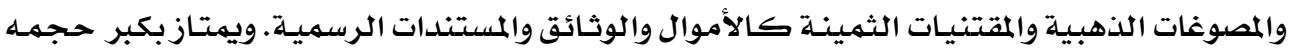

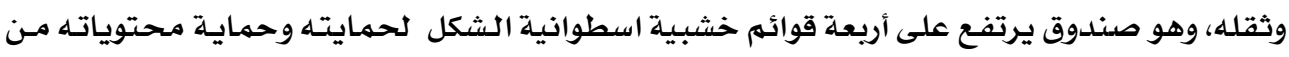
الرطوبـة.

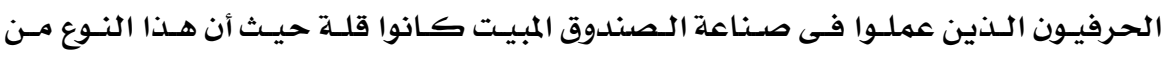

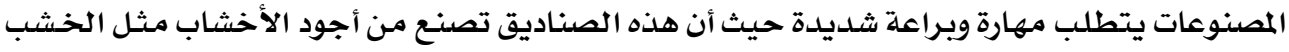

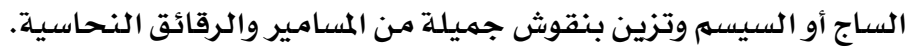
كما كانت تصنـع صناديق أخرى أقل جودة وأرخص ثمنا لأغراض مختلفة مثل حفظ المواد

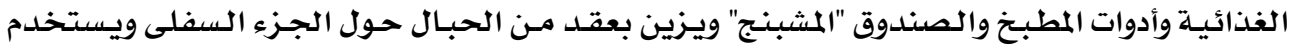

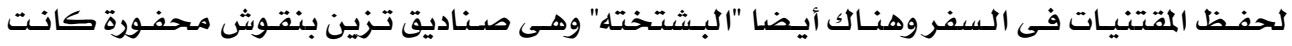

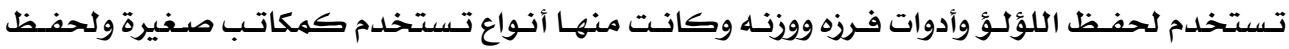

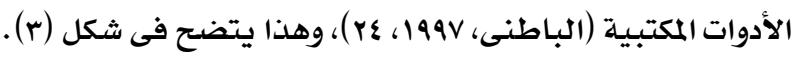
حرفة الحدادة:

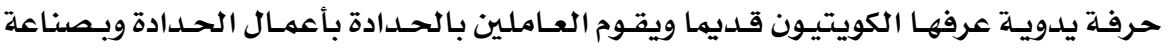

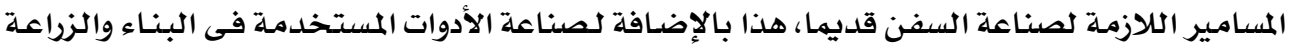

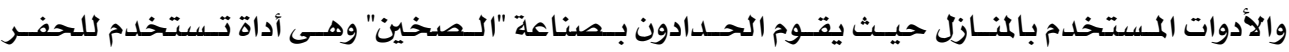

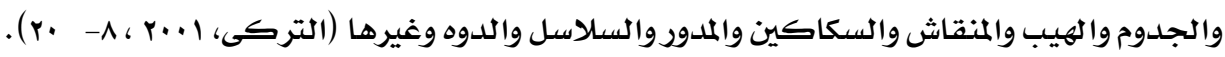

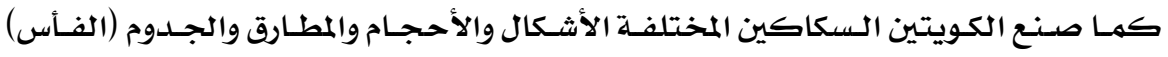
والهيب وهى قضيب ثقيل مدبب الطرف يستخدم فى عمليات الحفر والهدم والبناء. 


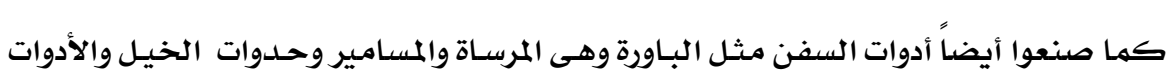

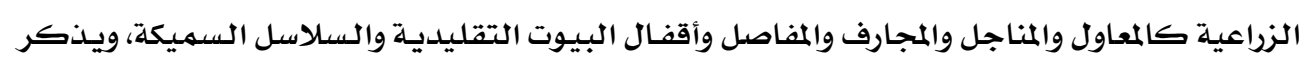

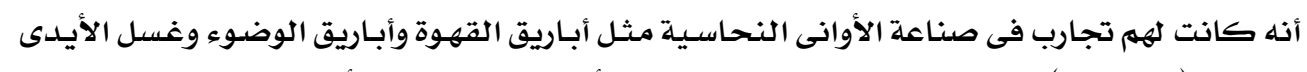

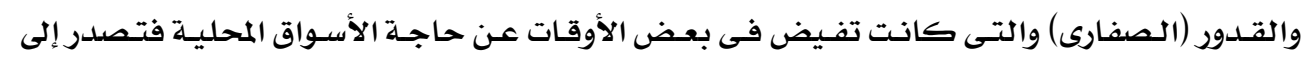

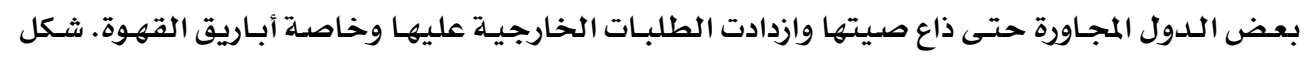

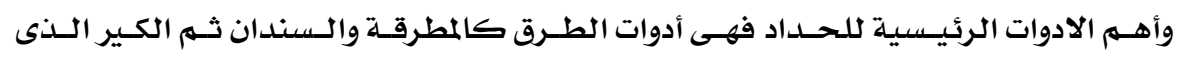

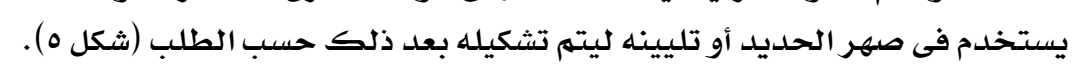

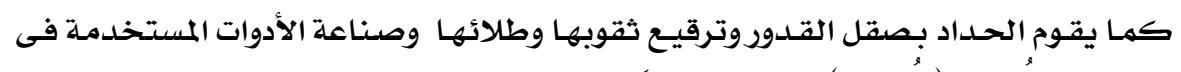

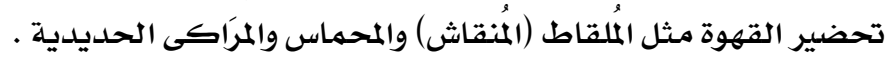

حرفة السدو:

من أهم الحرف اليدوية التى اشتهر بها أهل البادية، وهى تظهر تكامل ابن البادية مـع بيئتسه،

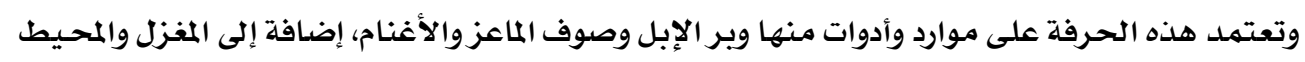

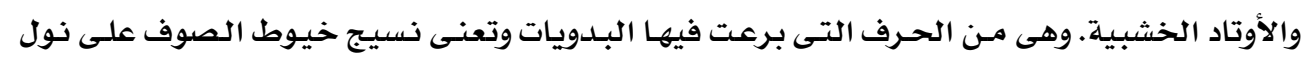

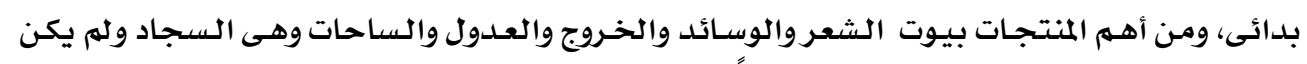

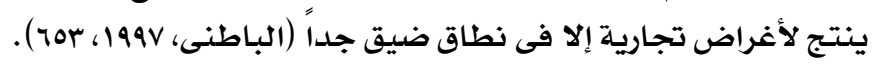

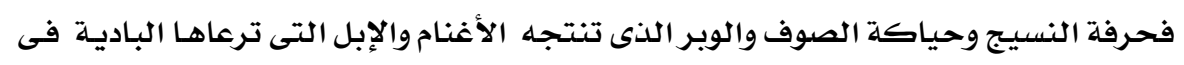

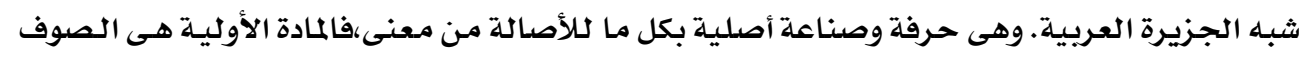

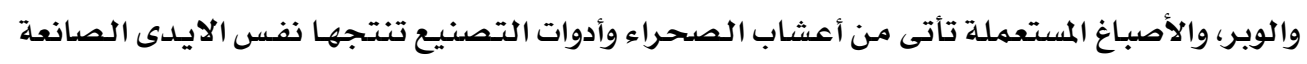

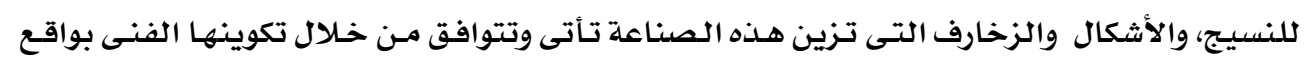

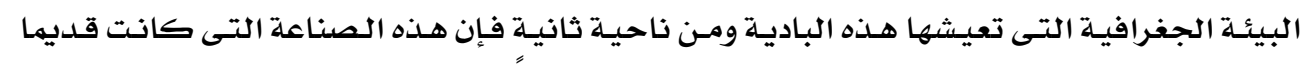

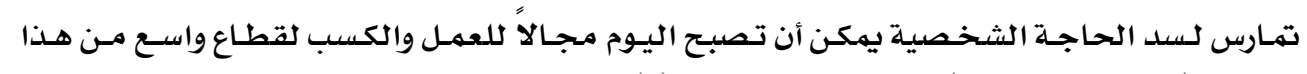

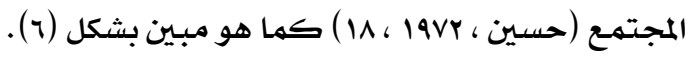

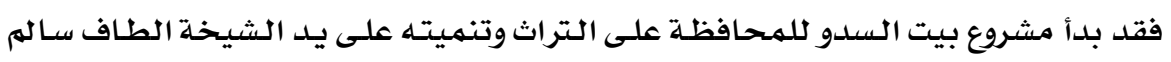

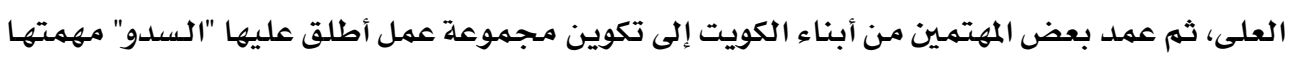

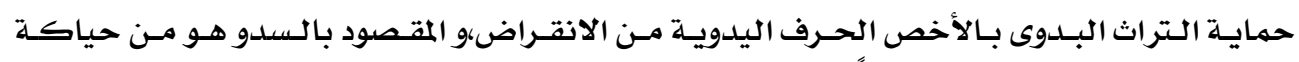

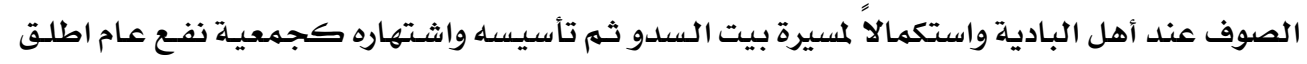

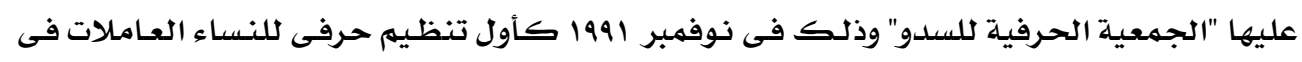

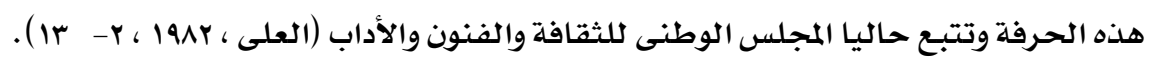




\section{حرفة صناعة الأوانى النحاسية:}

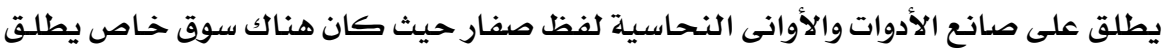

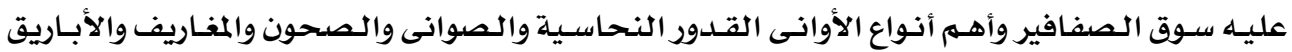

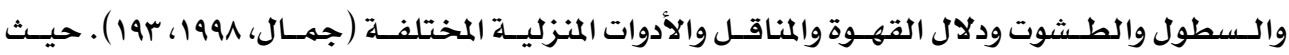

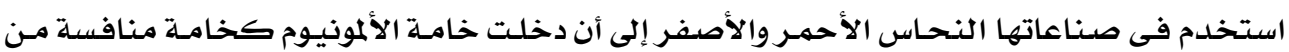

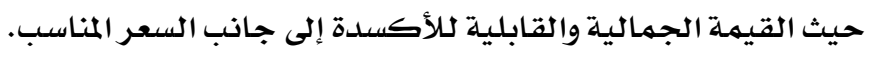

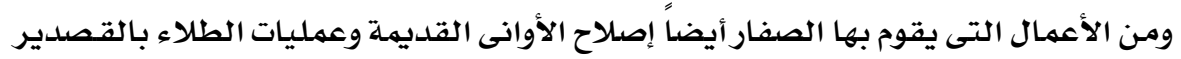

لأوانى الطعام من الداخل شكل (v) ). حرفة صناعة الحلى الشعبية:

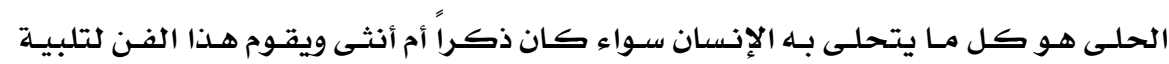

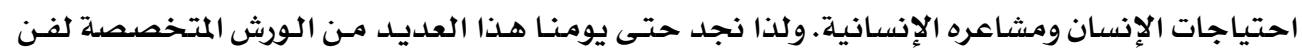

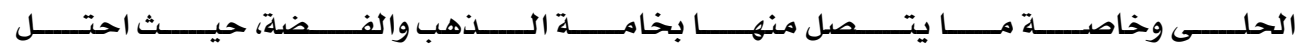

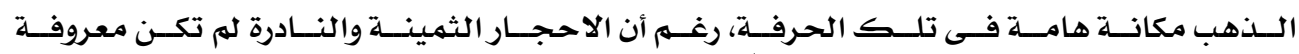

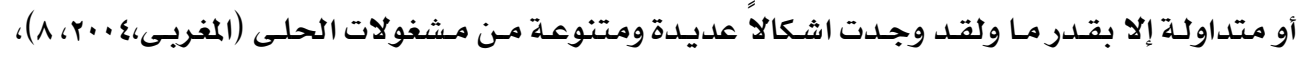

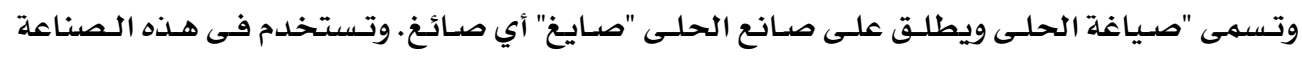

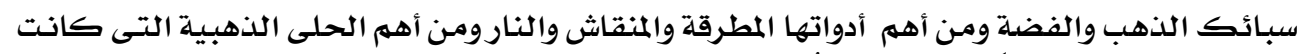

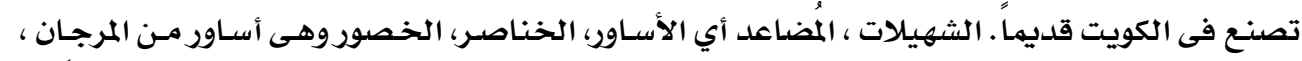

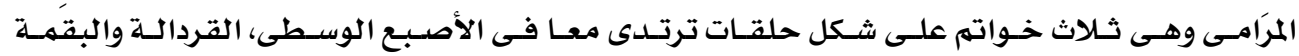

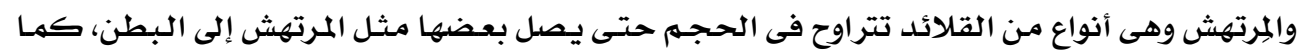

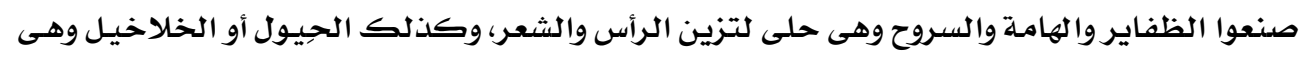

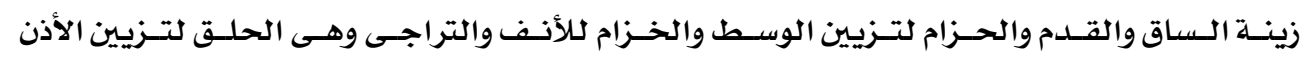

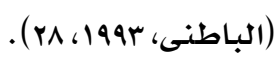

فغالبـا مـا نجـــ أن تلـك المشغولات الذهبيـة تتحلسى بالطـابع الشعبى البسيط مـن الأشـكال

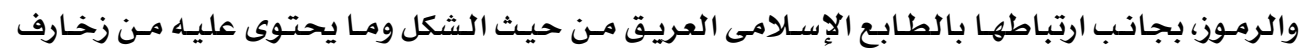

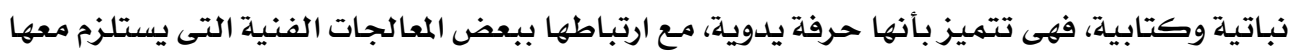

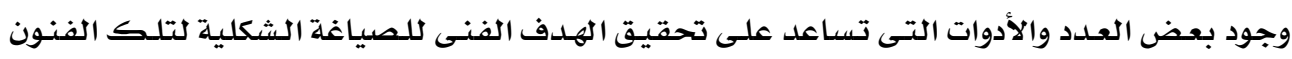

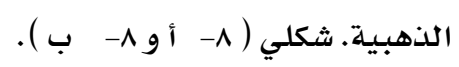

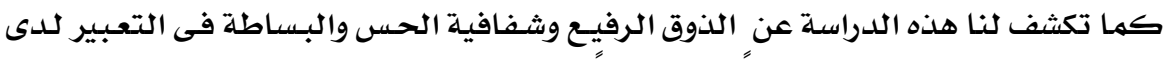

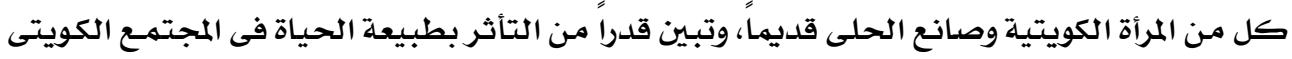

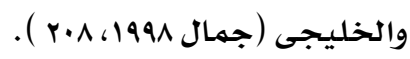

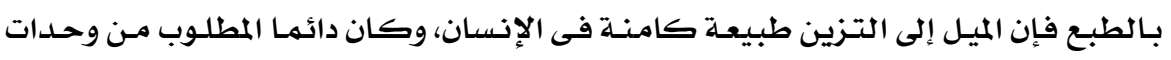

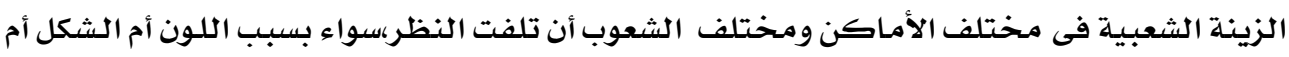




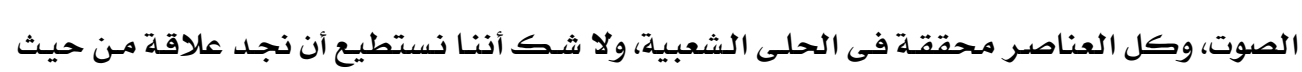

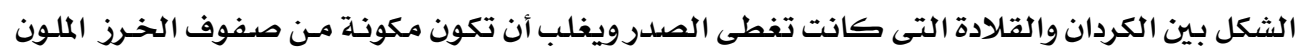

$$
\text { أو صفائح الذهب المشغول والمرصـع الكردان. }
$$

وأغلب زخـارف الحلى هندسية قوامها الخطوط والمثلثات، ويغلب أن تكون مشغولة بخيوط

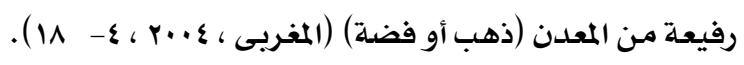

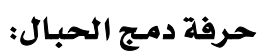

تـرتبط هـذه الحرفـة ارتباطـاً وثيقـاً بـالغوص والسفر، فهى تـزاول مـن قبـل البحـارة، لتغطيـة

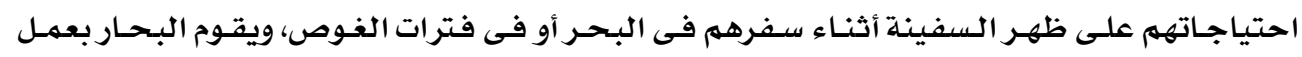

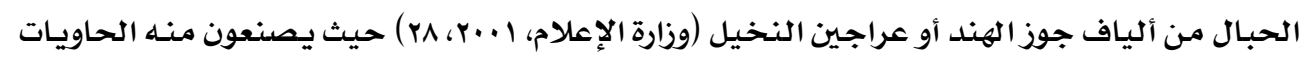

والصناديق.

\section{حرفة صناعة الفخار والخزف الشعبى:}

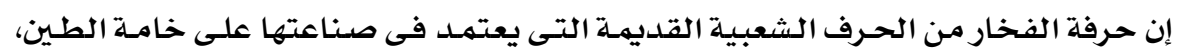

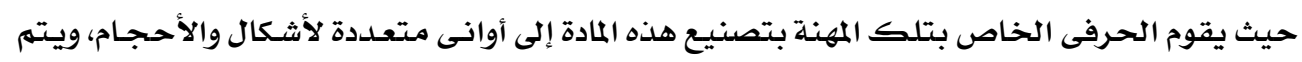

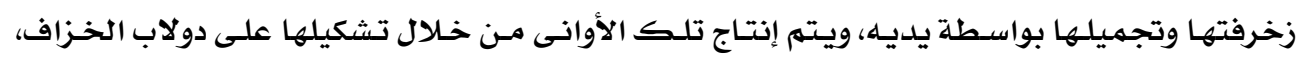

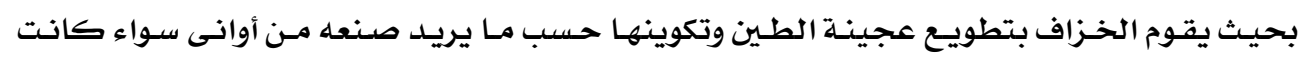

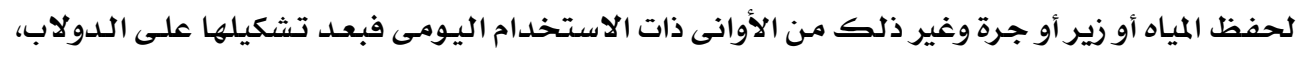

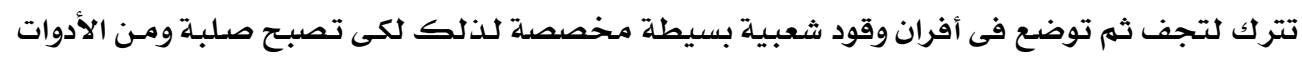

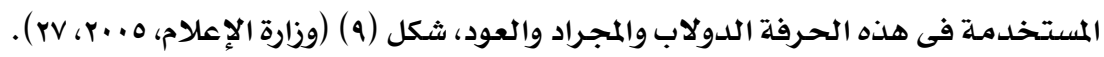
حرفة صناعة الأوانى والمستلزمات المنزلية من صفائح الحديلد:

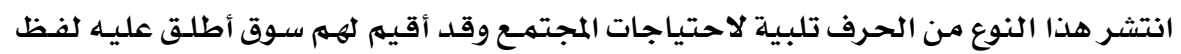

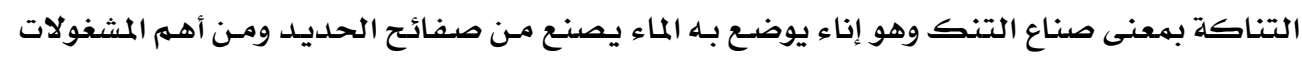

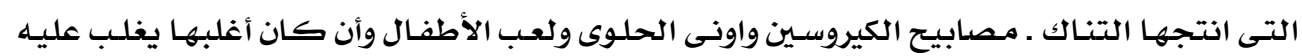

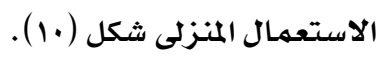
حرفة الخصاف: هو الحرفة الذى يقوم بصناعة مشغولات وظيفية متعددة الاغراض باستـخدام الخـوص مثل

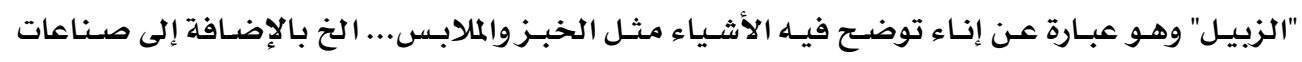

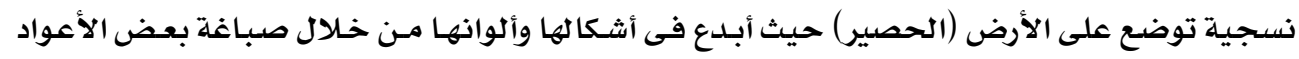

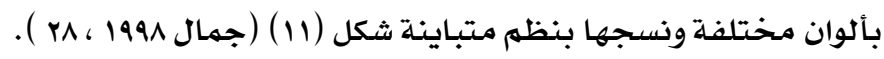
حرفة الأزياء الشعبية:

تعد الأزياء الشعبية النسائية والرجالية من المجالات الخصبة لممارسة الإبلداع والإبتكار، كمها

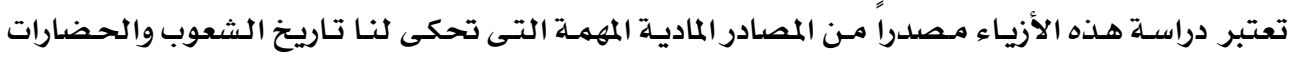




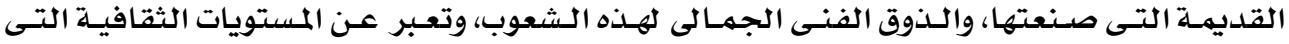

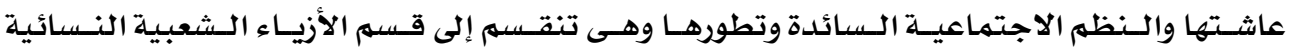

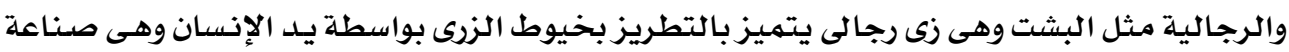

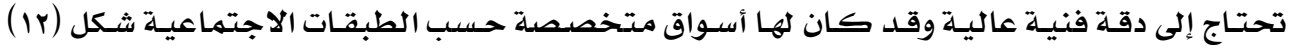

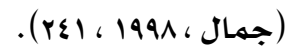
حرفة المشغولات الجلدية: وهي من الحرف الكويتية القديهـة ويطلق على صانعها "خراز" نسبة إلى أهم

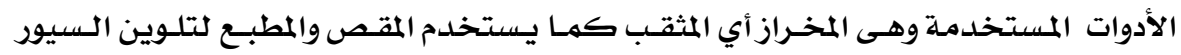

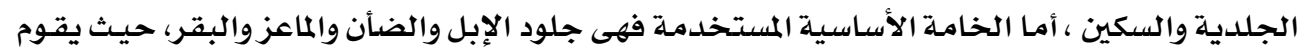

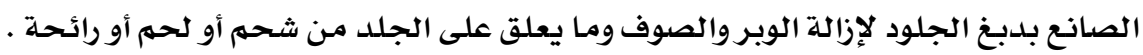

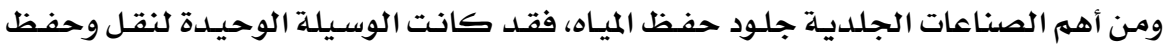

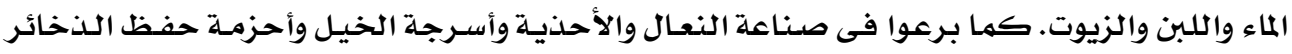

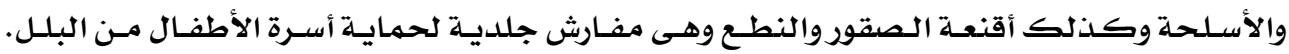

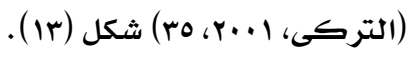

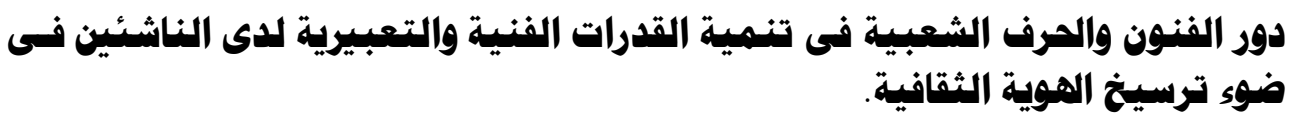

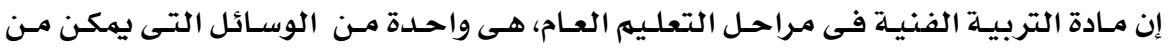

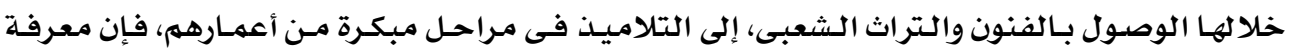

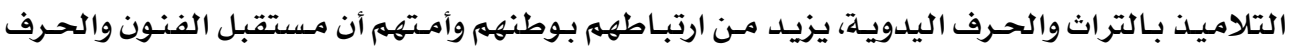

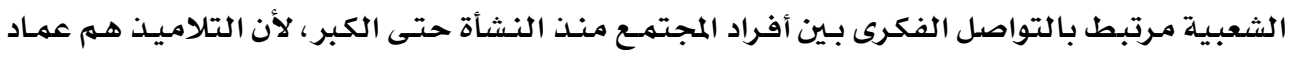

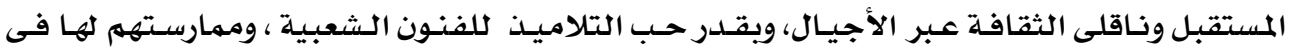

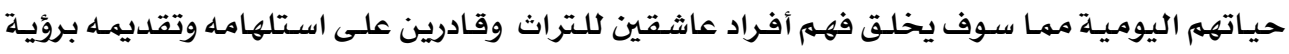

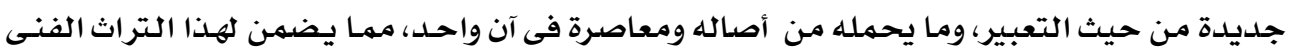

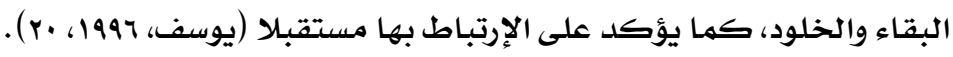

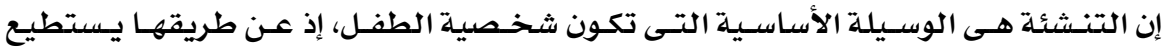

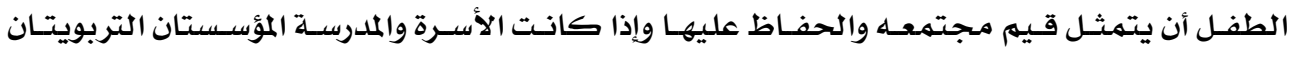

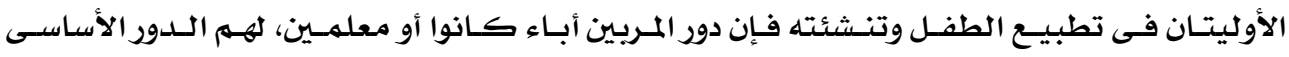

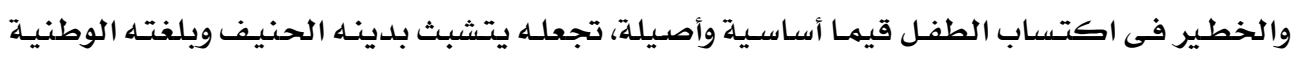

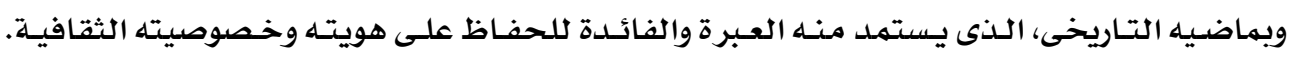

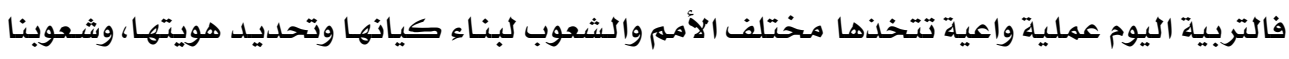

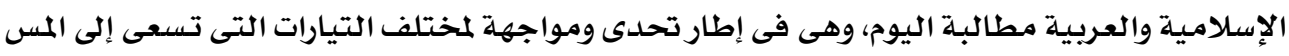

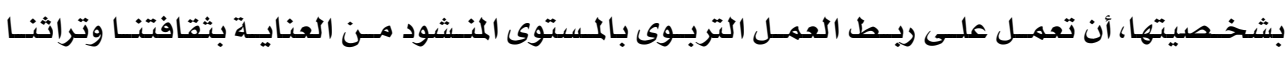


الحضارى، وتقديمها بشكل ممنهج وملائم حتى يستفيد منـه الطفل ويعمق خبر ته وينهى جسمـه ووعيه

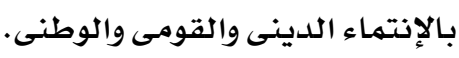

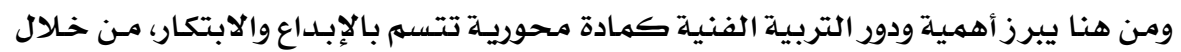

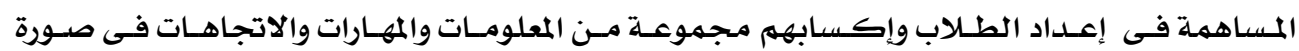
مختلفة فى البر امـج والمناهج التعليماد الهابية. إن ثقافـة الطفل لا تكون ثقافة إيجابيـة وبنـاءة مـالم تعمل على تكوين المواطن الصـالح ذنى

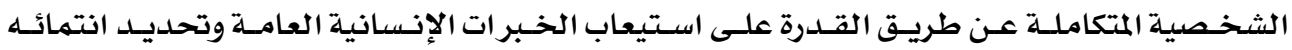

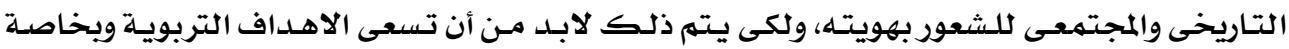

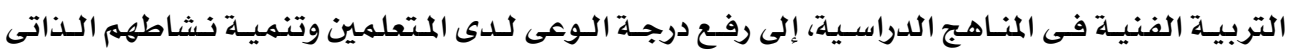

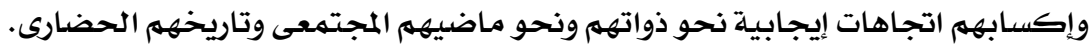
إن على التربية الفنية أن توفق فى جعل الطفل يعي بقيمة تراثه ويقدره ، باعتبار هذا التراث

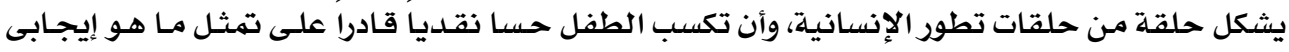

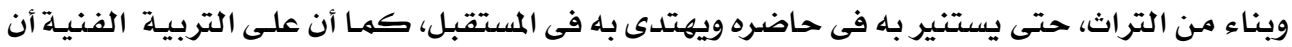

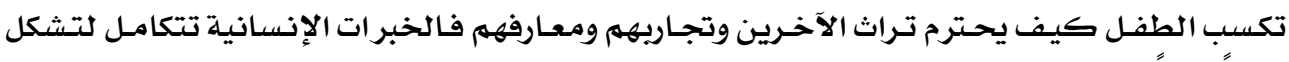

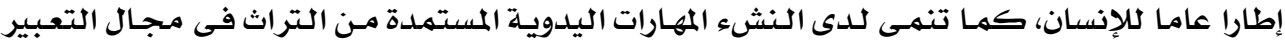
الفنى وإذا كان دراسـة التراث من الفنون والحرف الشعبية هى إحدى أهداف التربيـة الفنيـة بهدف

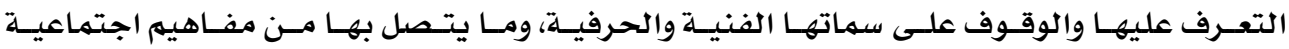

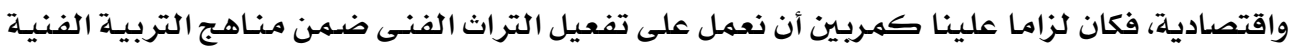

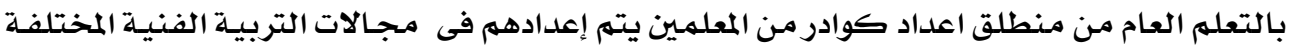

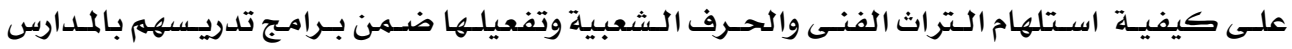

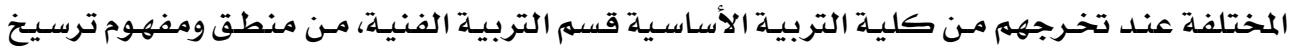
التواصل الفكرى والثقافى والحضارى بين معطيات الماضى وبناء المستقبل.

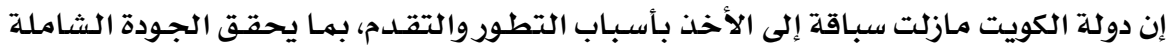

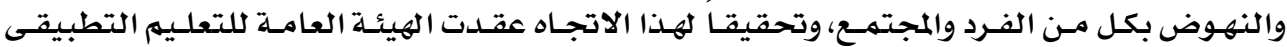

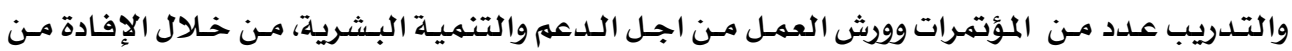

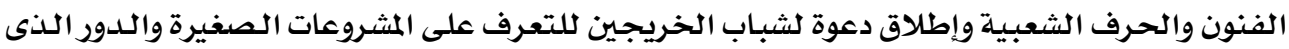

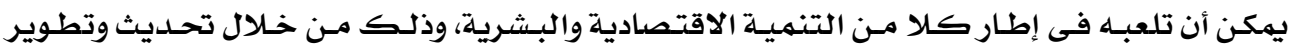

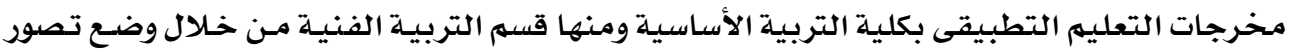

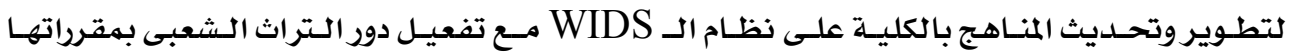


مجلة بحوث التربية النوعية - علد ع - بيناير r.lr

تصور مقترح لتفعيل دور الفنوز والحرف الشعبية ضمن مناهج تعليم الفنوز بالقسم من وجهة نظر الباحث:

تعتبر الفنون والحرف الشعبية من أهم المداخل التعليمية التي تحقق أهـداف التربيـة الفنيـة

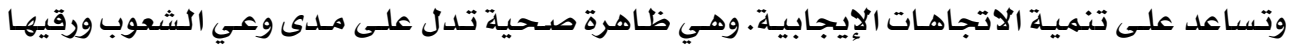

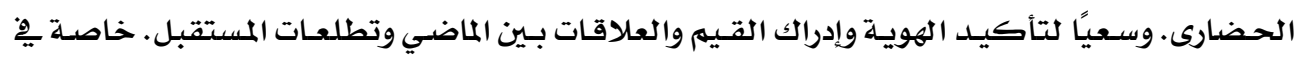

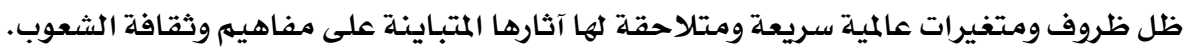
ويِّ هذا الجزء من البحث يسعي الباحث إلى القاء الضوء حهول أهمية ودور الفنـون والحـرف

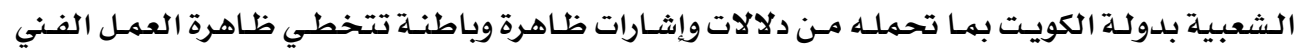

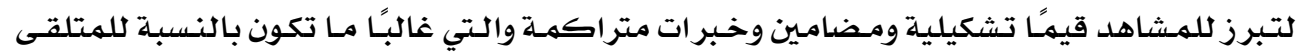

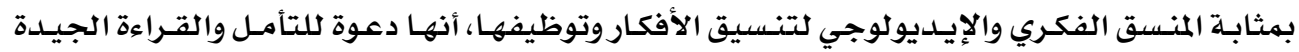

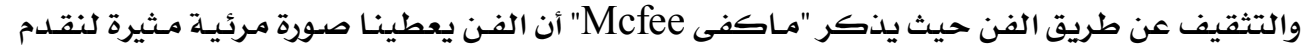

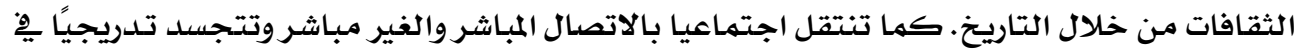

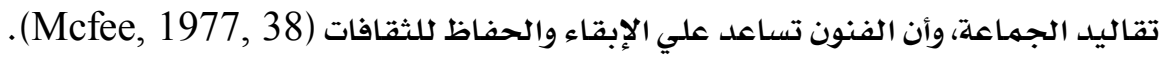

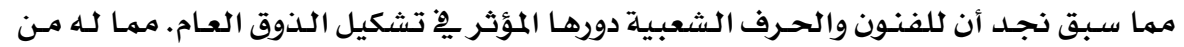

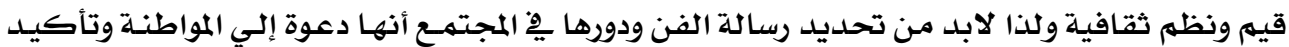
الذات وتفعيل دور الفنون والحرف الشعبية هِّ تعلهم الفن والتربية الفنية.

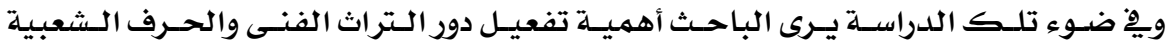

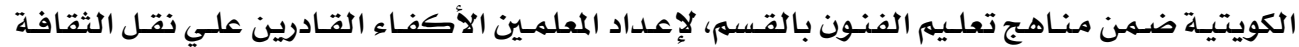

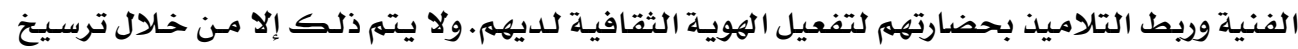

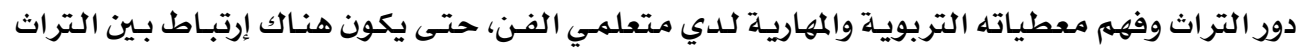

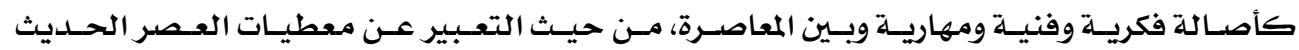
ومستجداته علي الساحة الفنية.

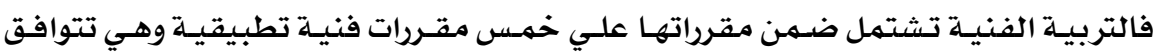

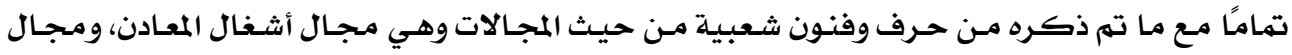

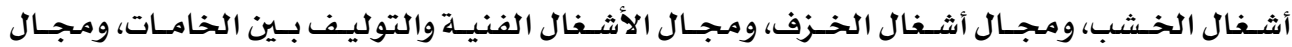

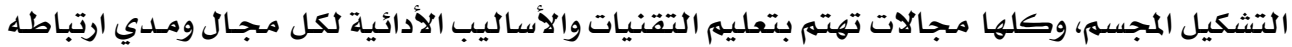

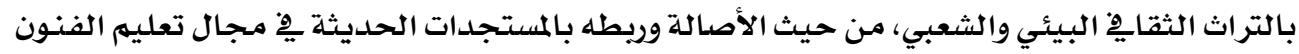

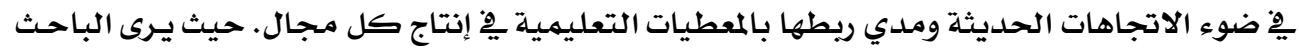

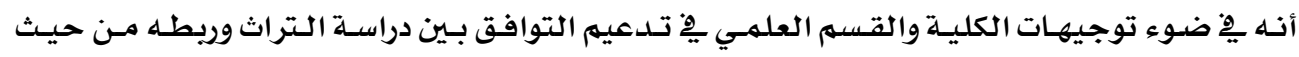

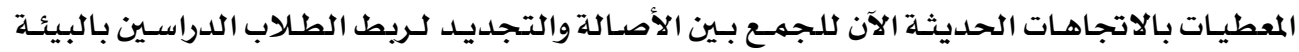

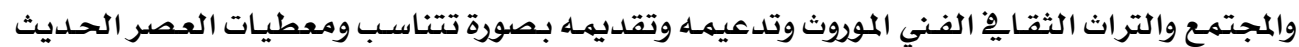
من حيث الشكل والمضمون. 
وِِِ ضوء ذلك يرى الباحث أهمية تدعيم تلك المقررات الفنيـة التطبيقيـة بمعطيات التراث

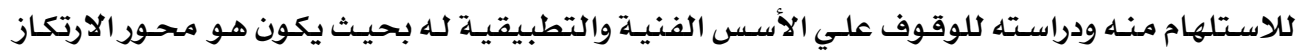

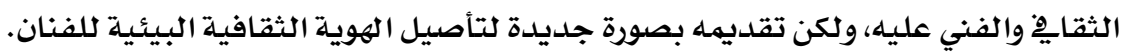
فقد اقترح الباحثث أن تشتهمل جميـع المقررات الفنيـة التطبيقيـة بقسهم التربيـة الفنيـة علدي

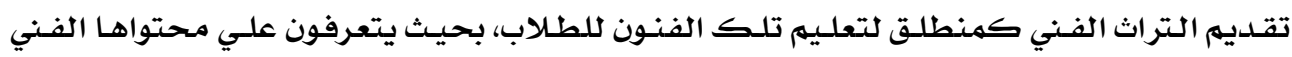

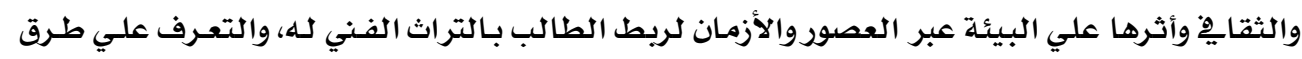

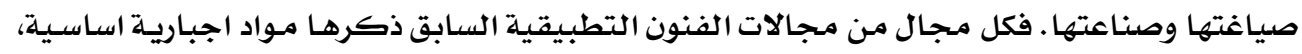

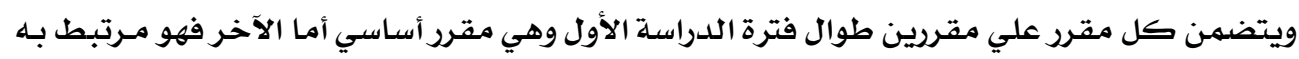

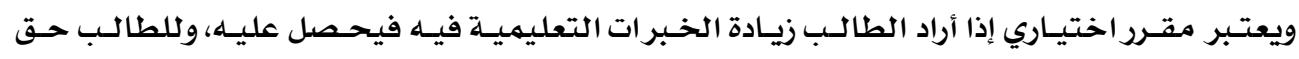

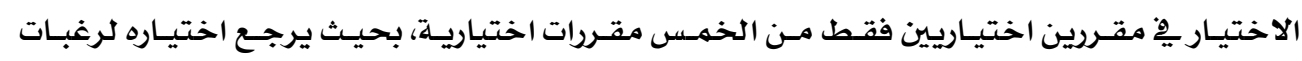

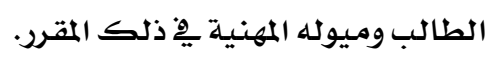

ومن هنا يرى الباحث أن تلك المقررات الإجبارية يِّ مجالات تخصصية مختلفـة تنهمي لدي

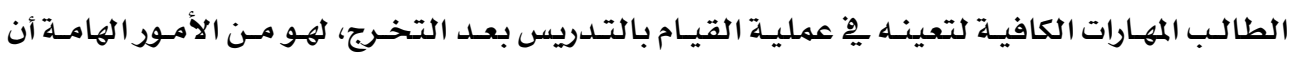

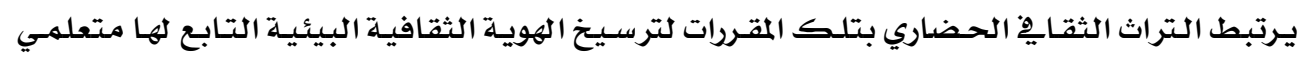

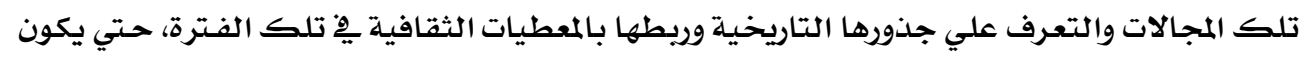

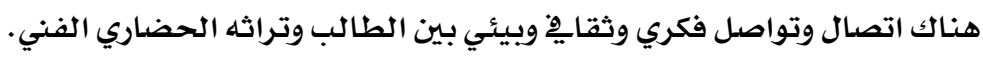

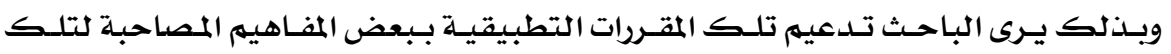

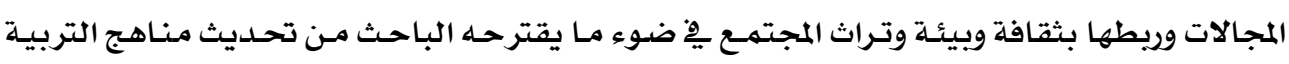

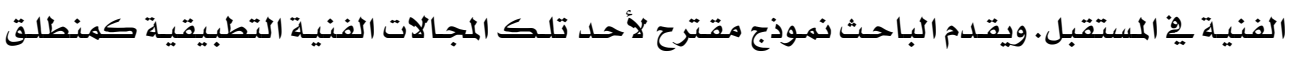

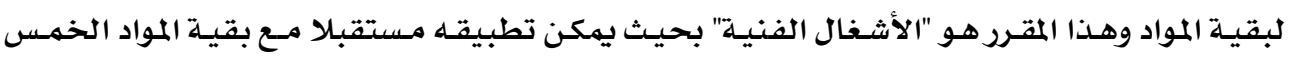

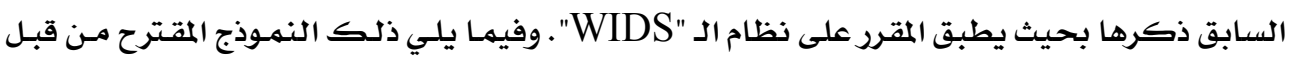

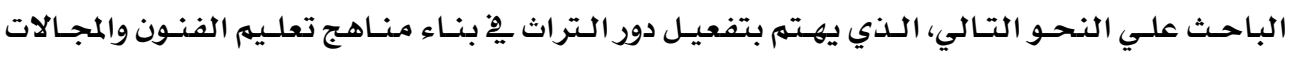
التطبيعية الأساسية بقسم النجو التبالي، البذية الفنية.

\section{الإطار العام للهقرر}

: كلية التربية الأساسية

الكلية

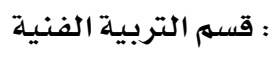

القسم العلمى

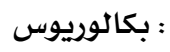

$$
\text { البرناميج }
$$

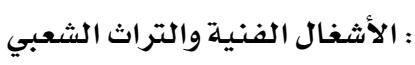

المستوي العلمي

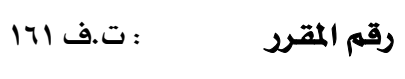

r: عدد الوحدات

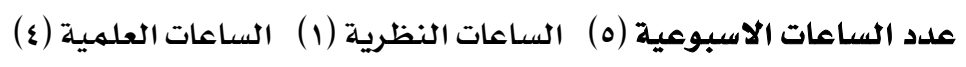




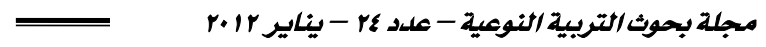

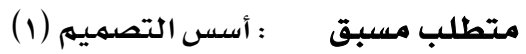

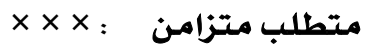

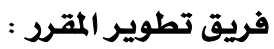

طريقة التدريس

\begin{tabular}{|c|c|}
\hline عدد السـاعات الأسبوعيـة & طرق التدريس \\
\hline 1 & مححاضرة \\
\hline$\varepsilon$ & تطبيقى \\
\hline
\end{tabular}

الفئة الطالابية المستهلفة

- ملاب وطالبات قسم التربية الفنية

توصيف المقرر

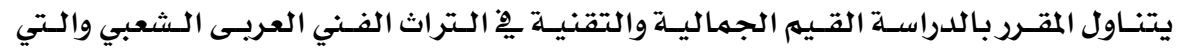

تؤسس مداخل تشكيلية قابلة للتحول والتجديد لتصميهم وتنفيذ مشغولات فنية معاصرة.

أهداف المقرر

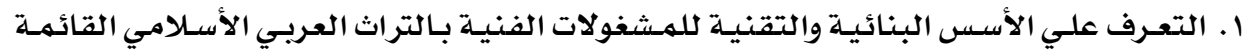

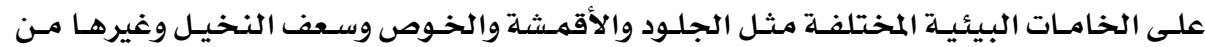

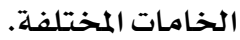

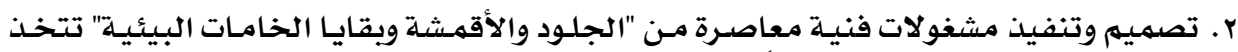

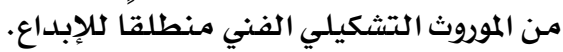

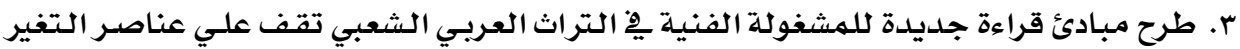
والثبات فيها. ع. تنمية القدرة علي التوافق والتكيف تجاه ثقافة المجتهـع بما يحقق التوازن النفسي والتوافق مـع متغيرات العصر. المراجع المقررة للطالب ميعران

• محمد حسـين جودى: الرسهم والأشغال اليدوية (1) (الأردن، دار المسيرة للنشر والتوزيع).

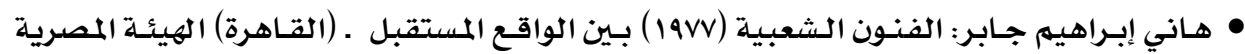
للكتاب.

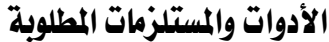

ا ـ أنواع مختلفة من الخامات "جلود طبيعية وبقايا الخامات البيئة مثل ـ قماث مختلف الملمسس"

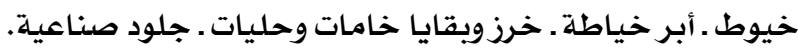
r r أدوات قص وخياطة ولصق ـ آلات حرق كهريائية. r. صبغات ملونة، نباتية، كيميائية، أوراق تذهيب ملونة حرارية، باردة. 
مخرجات التعليم العامة علي مستوي الكلية:

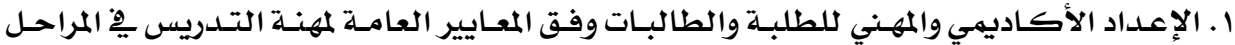

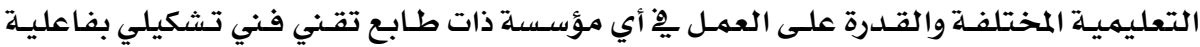

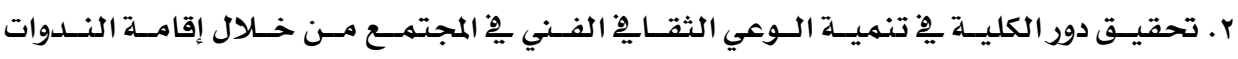

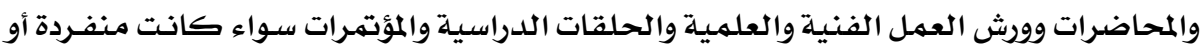
مشتركة مـع المؤسسات ذات العلاقة.

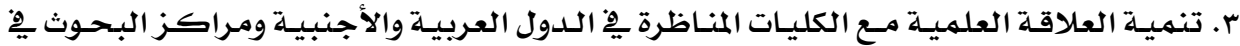

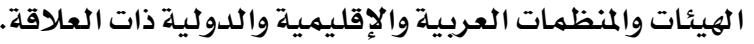

\section{مخرجات البرنامج علي مستوي القسم العلمي}

إعداد الدارسسين يِّ قسم التربيـة الفنيـة إعدادًا أكاديميًا وفنيًا لتوظيف قيم وأسس وأصسول

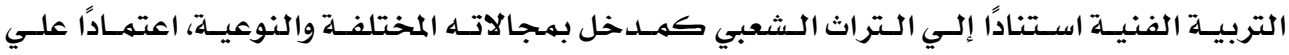

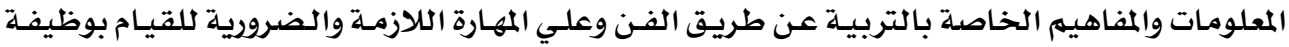

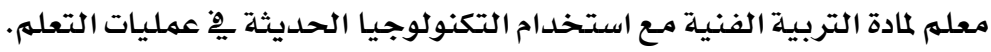

\section{القدرات الأساسية علي مستوي المقرر:}

ا ـ إدراك الصفات البصرية والتشكيلية للخامـة (جلود، أقمشة، خامـات بيئيـة مختلفة) هِي التراث

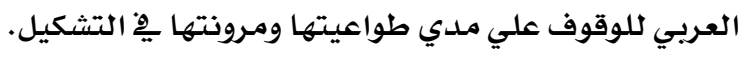

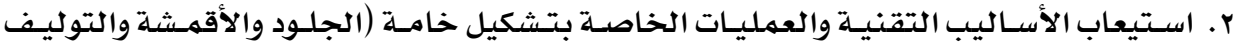

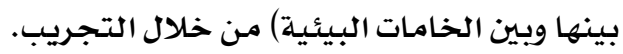

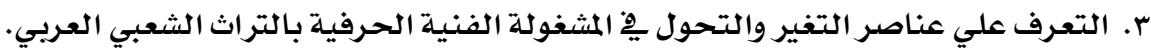

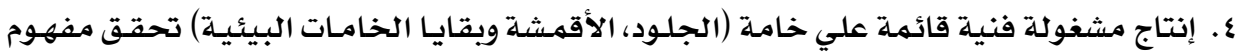

$$
\text { الأصالة والمعاصرة. }
$$

المعايير الخارجية أو (مصادر المعايير الخارجية إن وجدا):

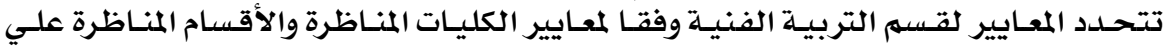

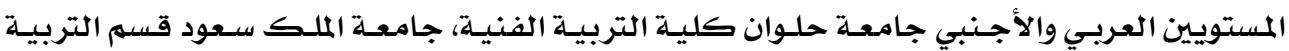

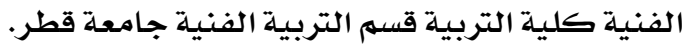




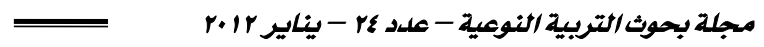

الكفايات : (عدد الكفايات في المقرر تعتمل علي المعلومات والخبرات العلمية والمدة الزمنية المقررة لتدريسه) الكفاية الأولي: إدراك الخصائص الجمالية والبنائية للمشفولة الحرفية في التراث الشبي العربي الإسلامى

الأهداف التعليمية للكفاية الأولى (ماذا سيتعلم الطالب حتي يحقق الكفاية)

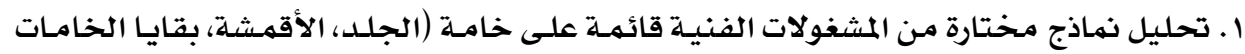

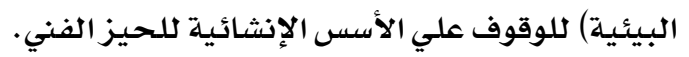

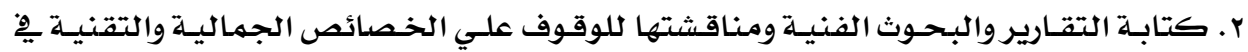

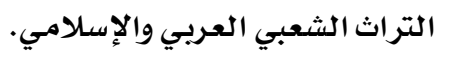

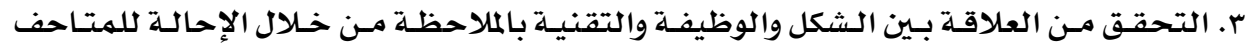

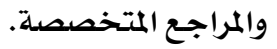

الكفاية الثانية: التعرف علي أهم التيارات والاتجاهات الفنية المعاصرة الـتي تتخـذ مـن المسوروث الفـني الشعبي

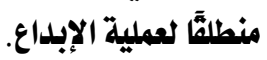

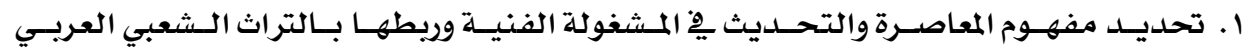

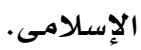

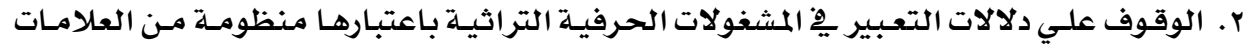

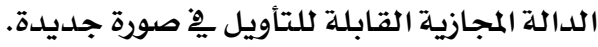

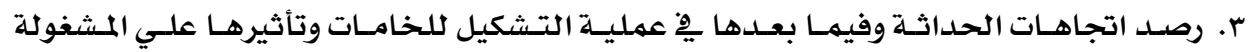
التراثية الفنية المعاصرة.

الكفاية الثالثة: الفهم للعلاقة بين الشكل والمضمون والتقنية في المشفولة الفنية في إطار الوظائف المستحدثة. ا . يحلدد تأثير الدلالة التعبيرية على القيم الجمالية وعناصر التشكيل يِ المثغولة الفنية.

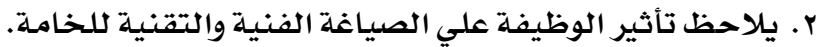
r. يدرك تأثير الخامـة علي الصياغة الفنية والتقنية للمشغولة الفيلة الفنية. الكفاية الرابعة: يكتسب المتعلم المهارات الأدائية والتقنية لتشكيل خامة الجلود الطبيعية والتوليسف بينهـا وبـين بقايا الخامات البيئية.

ا . عمليات تجريبية لتلوين الجلود وتظليلها بالصبغات والتمويه برقائق ورق الذهب. r. عمليات تجريبية لأسلوب الرسهم علي الجلد بواسطة ماكينة الجلينة الحرق والتوليف بينها وبين بقايا

$$
\text { الخامات البيئية. }
$$

r. عمليات تجريبية لأسلوب التفريغ والتطعيهم والتدكيك بالسيول بالسيور الجلدية.

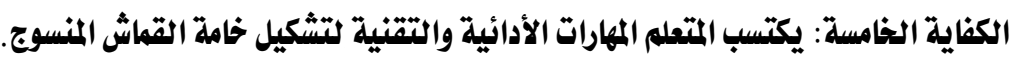

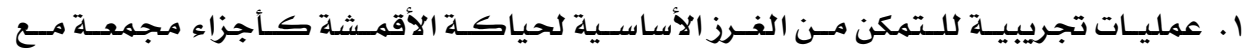
مجموعات خامات بيئية أخرى. 
r. عمليات تجريبية لتقنيات أثراء سطح القماش ِِّ المشغولة الفنيـة، بـالخرز، والحليات المصنعة..

إلخ

r. عمليات تجريبية لتحولات الأشكال وتكيفها لتتناسب مع طبيعة الخامة والتقنية.

الكفاية السادسة: القدرة علي إتتاج مشفولة فنية معاصرة تتخذل مـن خامـة "الجلـلـ أو الخامـات البيئيسة المختلفـة والأقمشة" كوسائط للتعبير.

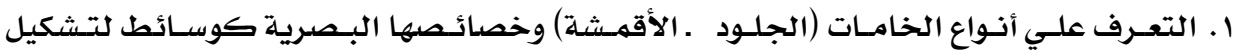

المشغولة الفنية.

r. تصـميم وتنفيـذ مشغولة فنيـة ثلاثيـة الأبعـاد تتخـذ مـن خامـة "الجلـود أو الأقمـشة" وســائط

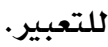

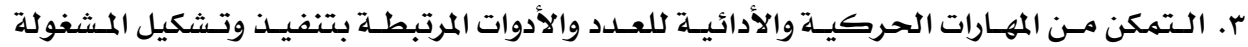

الفنية.

\begin{tabular}{|c|c|}
\hline النسبة المئوية & طرق التقييم \\
\hline$\%$. & ممارسات فنية تطبيقية \\
\hline$\%$. & مشروع فني \\
\hline$\%$. & ورقة بحث \\
\hline$\% \varepsilon$. & الاختبار النهائي \\
\hline$\% 1$. & المجموع \\
\hline
\end{tabular}

همترحات وتوصيات

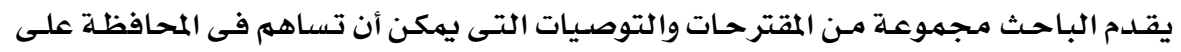

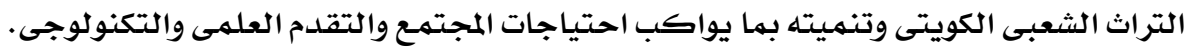

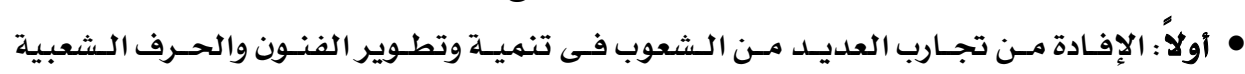

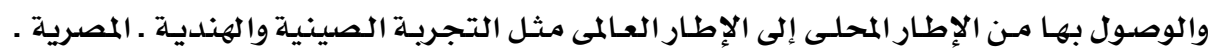

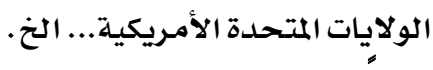

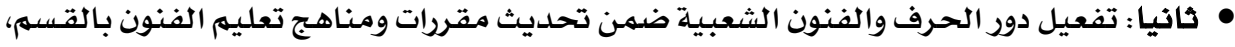

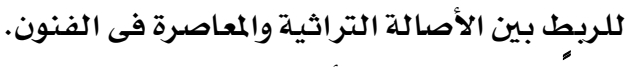

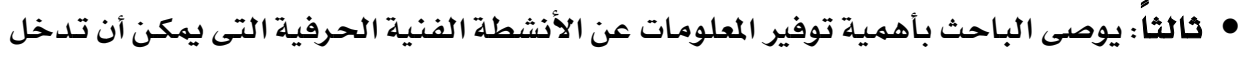

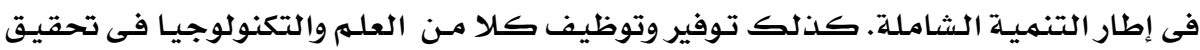

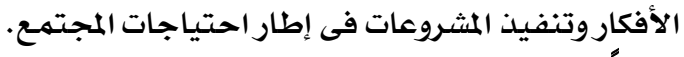

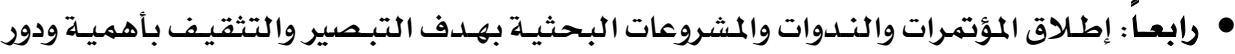

$$
\text { الفنون والحرف الشعبية. }
$$


مجلة بحوث التربية النوعية - علد ع - بيناير r.lr

• خامسـاً: أهميـة قيـام الحضانات وورش العهـل الـتي تهـتهم بـالفنون والحـرف الـشعبية مـن قبـل

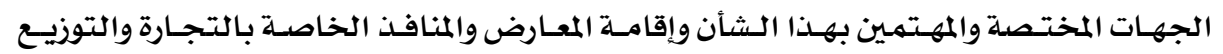

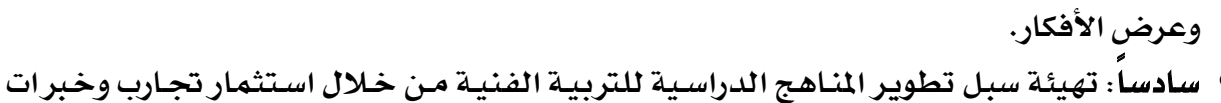

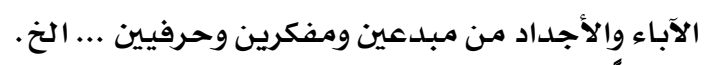

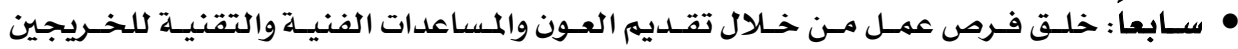

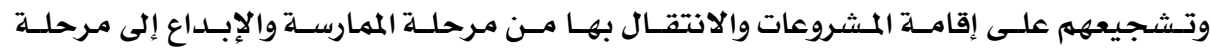

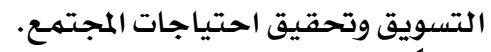

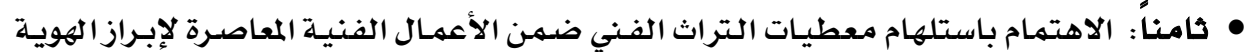

الثقافية العربية.
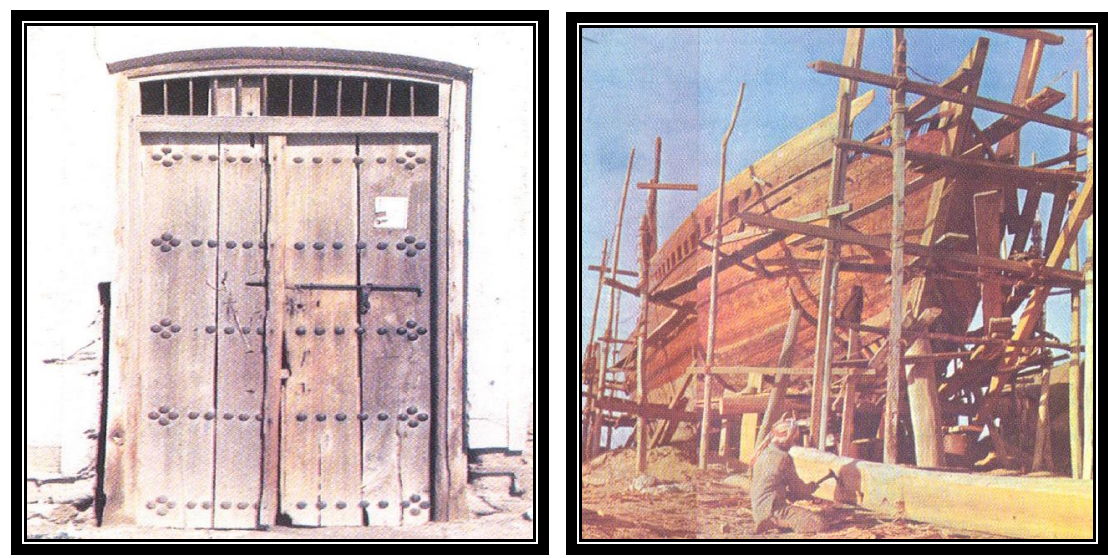

شكل رقم (r )

شكل رقم ( 1 )
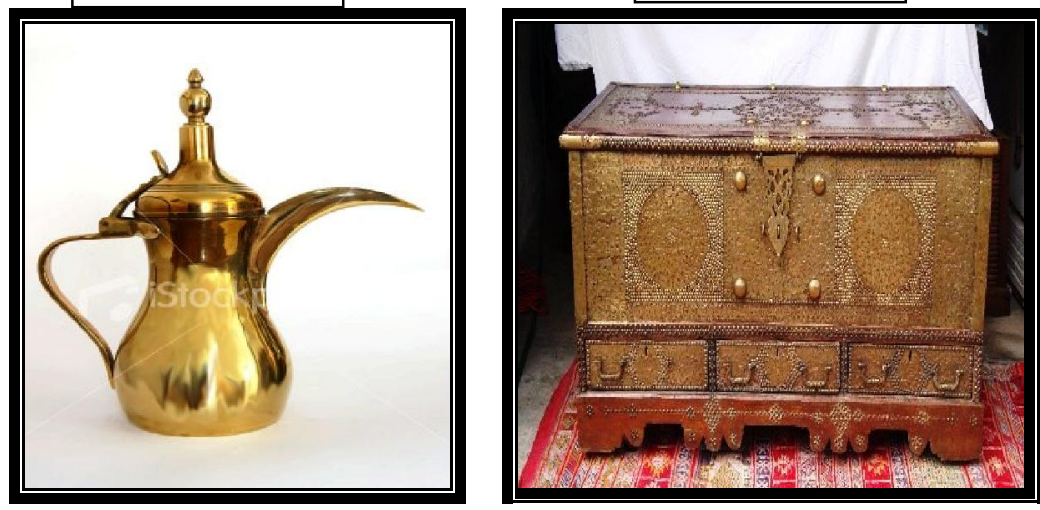

شكل رقم ( )

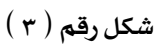




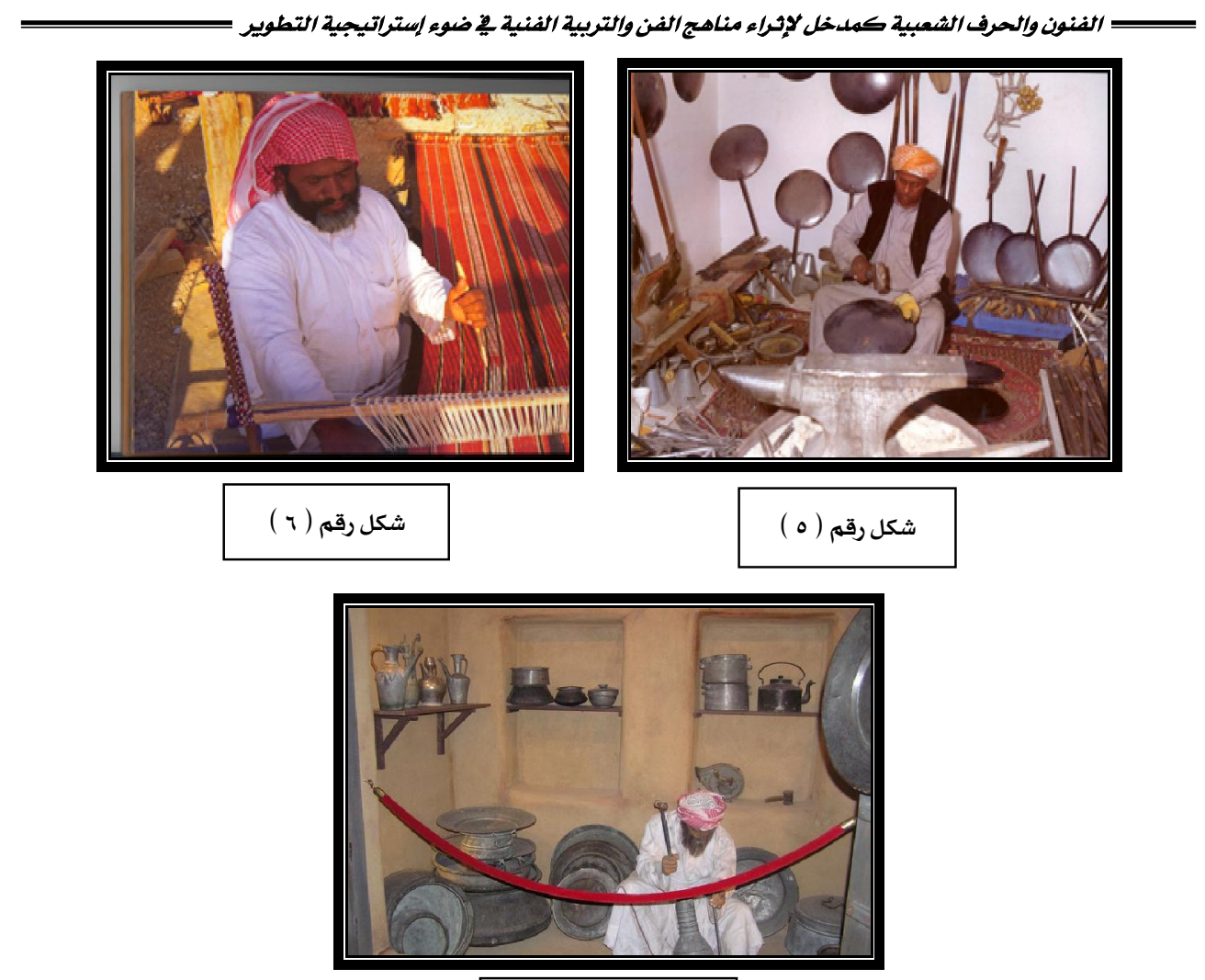

شكل رقم ( )
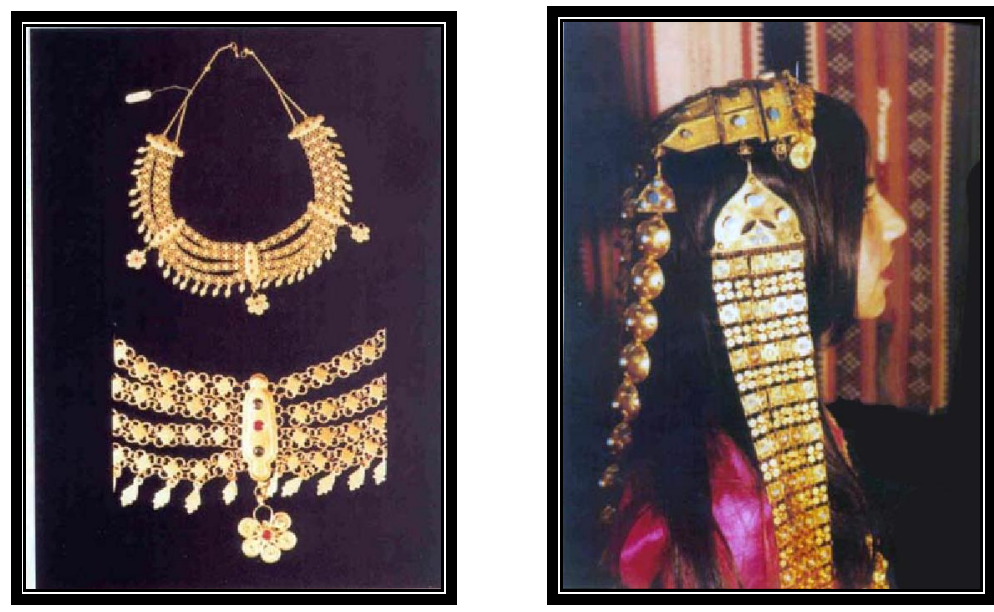

شكل رقم ( - - ب )

شكل رقم ( - ا ) 


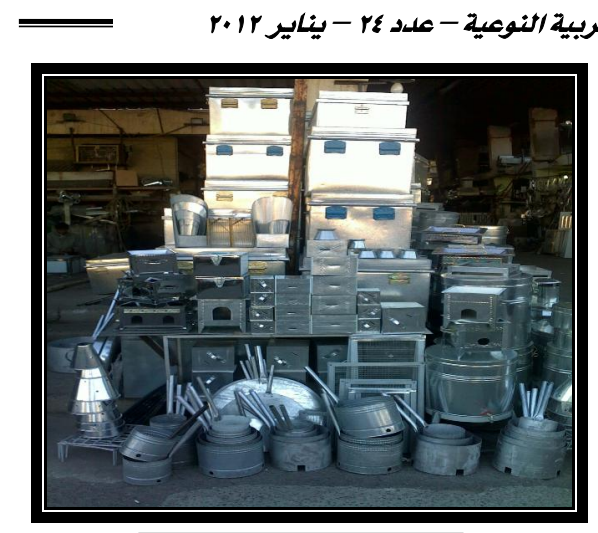

شكل رقم ( . )
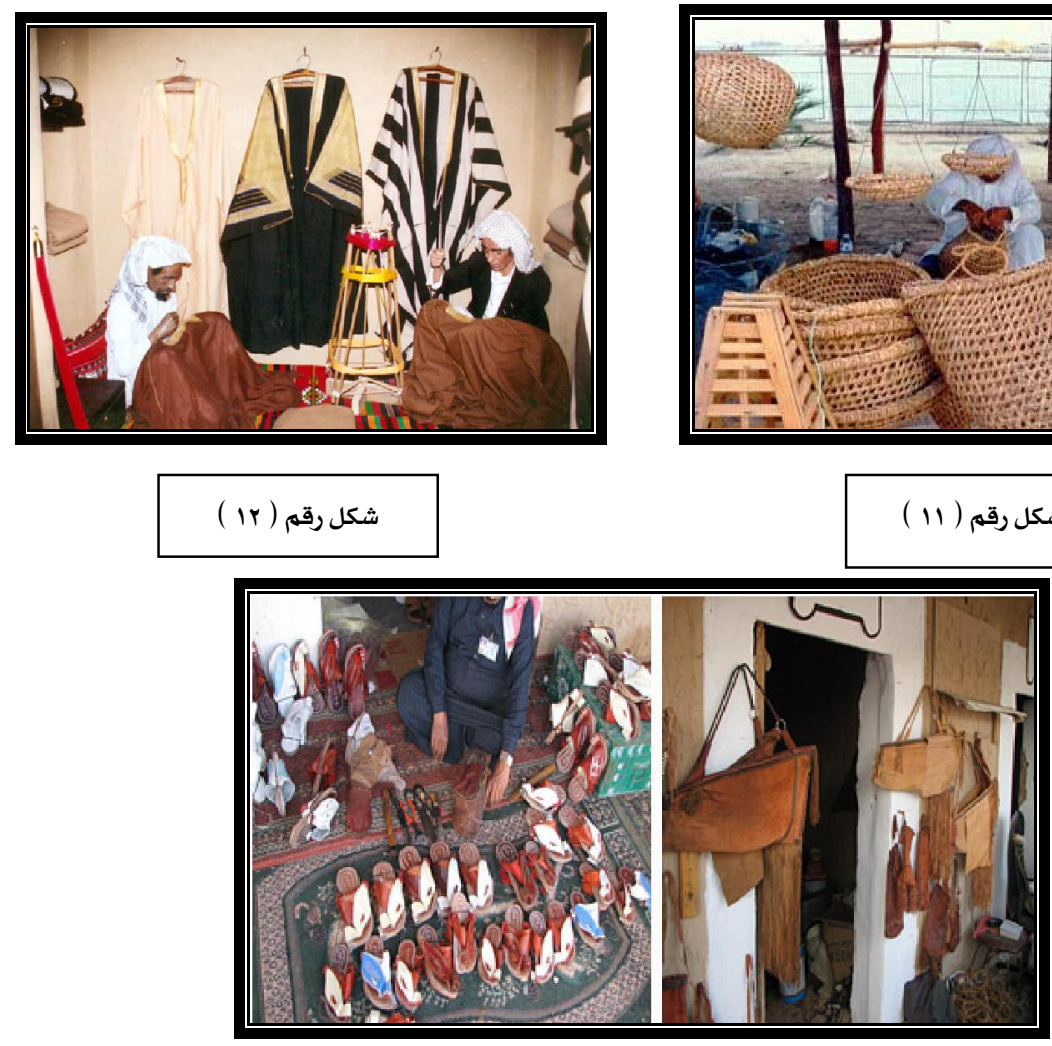

شكل رقم ( ri )

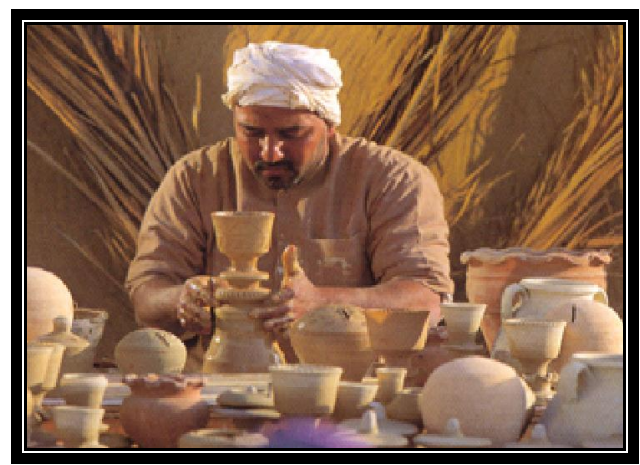

شكل رقم ( )

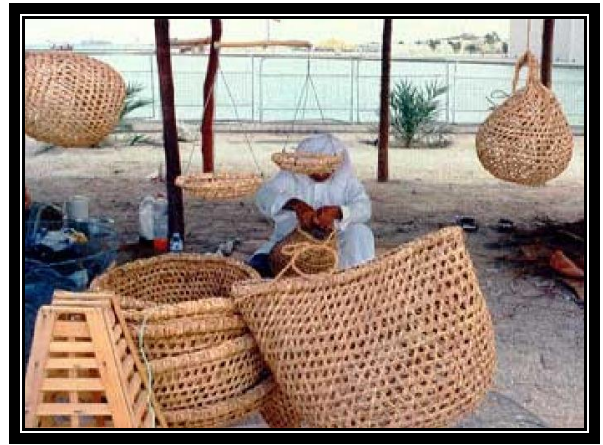

شكل رقم ( II ) 


\section{المراجع \\ المراجع العربية:}

ا. الألفي، أبو صـالح، 19V^، الفن الإسـلامي، أصولة، فلسفته، مدارسـة، القاهرة، دار المعارف. طا.

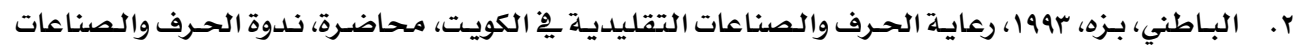

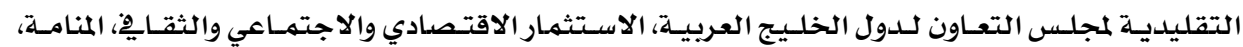

البحرين.

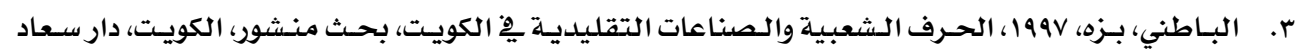

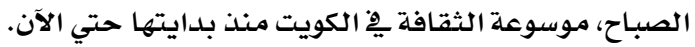

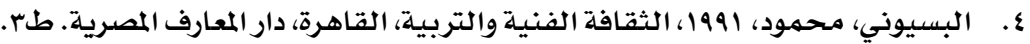

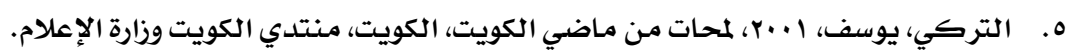

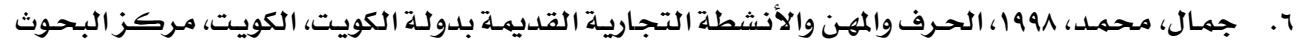
والدراسـات الكويتية.

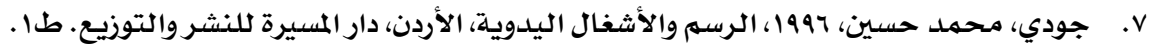

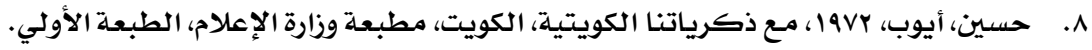

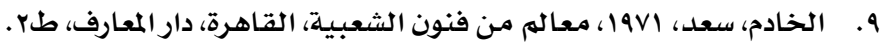

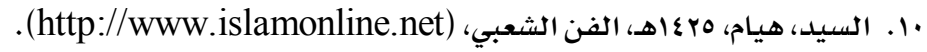

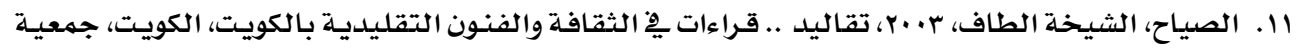

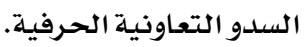

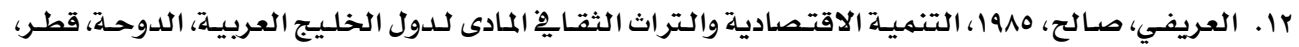

مركز التراث الشعبي.

rا. . العلي، الطاف سالم، ب1911، نشرة بيت السدو، الكويت، الطبعة الثانية.

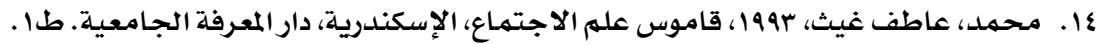

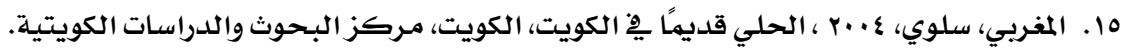

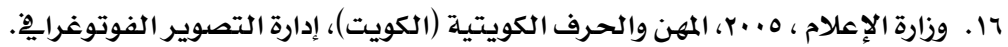

IV ا. اليحيب، هند، 199V، حرف تقليدية كويتية خليجية مشتركة، الكويت، المجلس الوطني للثقافة والفنون

والآداب، إدارة الآثار والمتاحف، متحنحف الكويت الوطني، قطاع الثقافة.

11 إم . يوسف، عبد الوقات، 1997، الطفل العربي والفن الشعبي، القاهرة، الدار المصرية اللبنانية.

المراجع الأجنبية

1- Bowman, Paddy; Zeitlin, Steve, (1993): Folk Arts in the classroom. Areport from the National Round Table on folk arts in the classroom Washington, D.C., May.

2- Nevinskas, Nancy, (1991): American Folk Art in the classroom arts, vo. 90 No 6, Feb.

3- www, Kuwait_history.net, 2003. منتدى تاريخ الكويت

4-Mcfee and R. Degge, (1977): Art Culture and Environment, Belmont, California, wads worth publishing company. 